\title{
Synergia terenów wystaw światowych i struktur przestrzennych miast-gospodarzy
}

\section{Izabela Sykta}

Instytut Architektury Krajobrazu, Wydziat Architektury, Politechnika Krakowska, isykta@pk.edu.pl

Streszczenie: Organizacja wystawy światowej to dla miasta-gospodarza szansa wykorzystania tego wydarzenia o globalnej skali dla własnego rozwoju poprzez m.in. poprawę jakości przestrzeni publicznych, transportu, bazy turystycznej, powstanie nowych obiektów kultury, ale też budowy wizerunku i wyższego pozycjonowania na arenie międzynarodowej. Wykorzystywane do budowy miasteczek Expo rozległe, często zaniedbane czy zniszczone przez przemysł tereny są odzyskiwane dla miasta, przyczyniając się do jego rozwoju. Po zakończeniu wystawy miasto otrzymuje tereny wyposażone w infrastrukturę architektoniczną, techniczną i zieleń oraz obiekty, które nadal funkcjonują i benefitują dla miasta. W wyniku tego procesu często udaje się zrealizować założenia synergii, rozumianej jako synteza energii, wyrażone umownie równaniem , $2+2=5$ ”. Spoiwem synergicznie wiążącym struktury post-Expo z miastem są jednoczące je ciągi czy strefy przestrzeni publicznych (np. Paryż 1889, Barcelona 1929, Seattle 1962), a także włączanie terenów post-Expo w systemy zieleni miejskiej (np. Barcelona 1888, Chicago 1893, 1933, Sewilla 1929, Nowy Jork 1939, 1964, Szanghaj 2010). Nie zawsze jednak potencjał terenów post-Expo jest efektywnie wykorzystywany. Czasami pozostają one izolowanymi wyspami, które wprawdzie dają atrakcyjną ofertę funkcjonalną (np. Sewilla 1992, Mediolan 2015), ale poprzez brak urbanistycznej synergii $\mathrm{z}$ miastem, nie generują takich korzyści, jak w przypadku struktur synergicznie powiązanych.

Słowa kluczowe: wystawy światowe, expo, synergia urbanistyczna, sieć synergiczna.

\section{Wprowadzenie}

Juliusz Żórawski w dziele O budowie formy architektonicznej twierdził „W odróżnieniu od wszystkich innych sztuk, które mogą tworzyć całości same w sobie, architektura działa wyłącznie przez dodawanie lub ujmowanie części w stosunku do uprzednio danych całości. Tym samym architektura polega na stałym i ciągłym kontynuowaniu istniejących układów. Architekt nie zaczyna swego dzieła od początku budując nową formę, ale zawsze zaczyna pracę nad formą, która już istnieje" [1]. Urbanistyka, rozumiana jako sztuka budowania miast, jest stałym dodawaniem nowych elementów do istniejących wcześniej całości - ulicy, placu, kwartału, dzielnicy, miasta. Powinno się to odbywać w duchu „dobrej kontynuacji” [1], gdyż celem dodawania części powinno być łączenie na rzecz dobra całości. Historia urbanistyki ilustruje wiele sposobów łączenia najróżnorodniejszych treści i form w obrębie jednej, ograniczonej jednostki przestrzeni, jaką jest makrownętrze miasta [2]. Czy licząca już 165 lat historia wystaw światowych obrazuje proces łączenia części dla osiągnięcia harmonijnej całości? W historii urbanistyki nie zawsze udawało się ten cel osiągnąć. Współczesny kryzys miasta, polegający na rozpadzie jego podzielonego na części organizmu i rozproszeniu środowiska kulturowego jest tego dowodem. W przypadku wystaw bywało różnie. Wiele z nich znacząco wpłynęło na podniesienie jakości przestrzeni miasta-gospodarza, ale były i takie, które nie wniosły zbyt wielu donio- 
słych wartości w całość, jaką jest miasto, skupiając się na podkreślaniu podziału i egocentrycznym dowartościowywaniu wydzielonych z całości części.

Synergia pojmowana jako synteza energii ${ }^{1}[2]$, w ujęciu urbanistycznym wydaje się być skuteczną strategią zmierzającą do tego, by z połączenia oddzielnych dotąd składników powstała kompozycja reprezentująca wartość większą niż wynik zwykłego dodania. Według T. Kotarbińskiego ${ }^{2}$, synergia umownie wyrażona wzorem ,2+2=5”, następuje wtedy, gdy współdziałające podmioty, osiągną więcej niż jeśli działają każde z osobna. Według A. Böhma do wartości reprezentowanych przez miasto, godnych ochrony i kultywacji, należy „takie ukształtowanie treści i formy, które dzięki skupieniu w obrębie wnętrza daje wyższą jakość przestrzeni miasta w stosunku do innego uformowania, złożonego z tych samych elementów" [2]. Jak w kontekście powyższych rozważań - zarówno tych dotyczących łączenia części, którego celem jest dobro nie części, ale dobro całości, za jaką możemy uznać miasto, jak i tych, wskazujących na znaczącą rolę synergii urbanistycznej W scalaniu „w jedną całość części w imię uzyskania wartości nieosiągalnych w separacji” [2] - rysuje się dziedzictwo architektoniczne, urbanistyczne i krajobrazowe wystaw światowych?

Organizowane od połowy XIX w. wystawy światowe zmieniały - czasami radykalnie - krajobraz miast. Często stanowiły kamienie milowe w rozwoju miast-gospodarzy, przekształcając dotychczasowe lost spaces [3] - tereny opuszczone, bezwartościowe w wysokiej jakości przestrzenie publiczne, funkcjonujące nadal po zakończeniu wystawy i przynoszące korzyści zarówno wizerunkowe, jak i ekonomiczne. Procesy te często następowały synergicznie, wiążąc tereny post-Expo z miastem siecią jednoczących je ciągów czy stref przestrzeni publicznych, z wpisanymi w oczka sieci wyróżniającymi się obiektami kultury (np. Paryż 1889, 1900, Barcelona 1929, Seattle 1909, 1962), a także włączając struktury post-Expo w systemy terenów zieleni miasta (np. Barcelona 1888, Sewilla 1929, Nowy Jork 1939, 1964, Szanghaj 2010), przyczyniając się do poprawy bilansu zieleni i podniesienia jakości życia mieszkańców. [4]

Pozytywny efekt wystawy światowej wykraczał czasami poza wymiar lokalny miastagospodarza. Dalekosiężnym dziedzictwem Wystawy Chicagowskiej 1893 r. był jej wpływ na naukę, kulturę, architekturę i planowanie miast. White City - efektowna i spójna kompozycyjnie wizja miasteczka ekspozycyjnego - obudziła bezprecedensowe publiczne zainteresowanie estetyką miast i kształtowaniem terenów miejskich, co w sferze urbanistycznej dało początek nowemu podejściu do planowania miast, wyrażającym się w interdyscyplinarnym traktowaniu przedsięwzięć planistycznych oraz eksponowaniu czynnika kompozycji. Amerykanie fascynację możliwościami transformacji ponurego środowiska urbanistycznego swoich miast wyrazili w postaci City Beautiful Movement - społecznego ruchu na rzecz piękna miast oraz realizacji planów „upiększenia miast”. Istniejące w wielu amerykańskich miastach krajobrazowo kształtowane tereny i zielone bulwary stanowią rezultat działań inspirowanych Wystawą Chicagowską.

Nie zawsze tak efektywnie wykorzystywano potencjał terenów post-Expo. Czasami pozostawały one wypreparowanymi w tkance przestrzennej miasta częściami (np. Sewil-

1 Synergia rozumiana jako synteza energii została zilustrowana w diagramach P. Geddesa (City in Evolution, London 1913). Współcześnie pojęcie to stosował Henri Van Lier (Le nouvel age, Paris 1962) dla określenia stosunków maszyna - maszyna i człowiek - maszyna. W „filozofii konstrukcji” terminu tego używał R.B. Fuller (Synergetics explorations in geometry of thinking, New York 1975). W odniesieniu do przestrzeni architektonicznej termin ten został zastosowany przez A. Böhma w referacie „Architektura synergiczna”, Komisja UiA PAN, Kraków 1976. Ten sam autor rozwinął pojęcie synergii w ujęciu urbanistycznym [w:] Böhm A., O budowie i synergii wnętrz urbanistycznych, Kraków 1981. [2]

2 Mała encyklopedia prakseologii i teorii organizacji, PWN, Warszawa 1978 
la 1992, Mediolan 2015), wprawdzie atrakcyjnymi, ale które poprzez brak urbanistycznej synergii nie były w stanie oddać swojej energii na rzecz miasta jako całości. W artykule pokazano przykłady zarówno tych wystaw światowych, które przyniosły wiele wszechstronnych lokalnych i ponadlokalnych profitów, jak i rozwiązań mniej skutecznych, w których zabrakło synergii w powiązaniu terenów post-Expo ze strukturami przestrzennymi miast. Można by nawet postawić tezę, że im większa była synergia urbanistyczna pomiędzy strukturami wystawowymi i miejskimi, tym bardziej korzystny był dla miastagospodarza wynik równania ,2+2=5”.

\section{Analiza wybranych przykładów wystaw światowych}

PARYŻ 1855, 1867, 1878, 1889, 1900, 1937. Kolejne wystawy, zmieniające krajobraz Paryża od 1855 r., odcisnęły w mieście tak wyraziste ślady, że dzisiejszy jego obraz jest $\mathrm{w}$ dużej mierze przez nie zdeterminowany. Wystawy ostatecznie utrwaliły oś Pola Marsowe - Trocaderó jako główne tereny ekspozycyjne, włączając także lokalizacje towarzyszące, jak: Pola Elizejskie, Esplanade des Invalides, nabrzeża Sekwany, Lasek Vincennes, wiążąc je ze sobą w rodzaj konstelacji siecią alei, przecinających się w punktach, stanowiących kolejne cele oznaczone w przewodnikach wystaw. Wzajemne relacje pomiędzy terenami i obiektami wystawowymi były realizowane zgodnie z zarysowaną przez Eugene Haussmana w drugiej połowie XIX w., zasadą wielkich, powiązanych ze sobą i krzyżujących się osi, akcentowania przecięć osi placami, eksponującymi wyróżniające się budowle publiczne. Oś Pola Marsowe - Trocaderó, sygnalizowana wertykalną dominantą wieży Eiffla, ma nadzwyczaj silne pole działania formalnego [1] w strukturze urbanistycznej miasta, porównywalne do wielkiej osi Luwr - Plac Etoile. Pola Marsowe, zanim stały się lokalizacją wystaw, pozostawały terenem otwartym, rodzajem błoń, wykorzystywanych do różnych celów, wymagających niezabudowanej i rozległej przestrzeni, jak np. plac ćwiczeń wojskowych, uroczystości państwowe, defilady, wyścigi konne itp. [5] Tak więc dla organizacji wystaw wykorzystano tereny o świetnej centralnej lokalizacji, niezabudowane i doskonale przygotowane do wznoszenia tymczasowych obiektów ekspozycyjnych. Pierwsze wystawy 1855 i 1867 opierały się na modelu jednego wspólnego obiektu wystawowego. Wystawa 1855 r. mieściła się w Palais de'l Industrie, ustawionym przy Polach Elizejskich z aneksem w postaci przeszklonej galerii, usytuowanej wzdłuż Sekwany. Na pierwszą na Polach Marsowych wystawę 1867 r. wzniesiono ogromną okrężną galerię, projektu J.B. Krontz'a, otoczoną swobodnie projektowanymi terenami ogrodowymi. Krajobraz kolejnych wystaw na Polach Marsowych kształtowały od 1878 r. komponowane w kwartałach kompleksy różnego rodzaju hal i pawilonów w otoczeniu otwartych przestrzeni publicznych i ogrodów. Odtąd również z Polami Marsowymi wspólną osią powiązano tereny po drugiej stronie Sekwany, gdzie wybudowano pałac Trocaderó (proj. G. Davioud) z przeznaczeniem na galerię sztuki. Układ ten stał się podstawową kanwą organizacji przestrzennej wszystkich późniejszych paryskich wystaw, na stałe wpisując się w tkankę urbanistyczną miasta. W 1889 r. na osi Pola Marsowe - Trocaderó pojawiła się wieża Eiffla - nowa brama do terenów wystawowych, która w sposób najbardziej radykalny i trwały zmieniła krajobraz Paryża, stając się symbolem o szerszym znaczeniu i bezkonkurencyjną światową atrakcją turystyczną. Odtąd kontrowersyjna 300-metrowa wieża dominowała nad terenami kolejnych wystaw i nad całym miastem. Wystawa 1900 r. wprowadziła nowe obiekty ekspozycyjne o bombastycznej architekturze, utrzymanej w oficjalnej stylistyce II Cesarstwa, jak Grand Palais (proj. H. Deglane, A. Louvet, A. Thomas, C. Girault), Petit Palais (proj. C. Girault) czy most Aleksandra III. Na wystawę 1937 r. wymieniono niefortunny pod względem architektonicznym „mauretańsko-bizantyjski” Pałac 
Trocaderó na monumentalne klasycyzująco-modernistyczne założenie Palais de Chaillot (proj. L.H. Boileau, J. Carlu, L. Azéma), domykające oś Pól Marsowych tarasowymi ogrodami (proj. J.C. Alphand) z kaskadowymi fontannami. Trwałym dziedzictwem architektonicznym wystaw paryskich są identyfikowane z nimi, wyżej wymienione znamienite budowle, na czele z wieżą Eiffla, ale też obiekty o mniejszej skali, stanowiące ikoniczne znaki w przestrzeni miejskiej, jak chociażby secesyjne stacje paryskiego metra, wybudowane na wystawę 1900 r. (proj. H. Guimard) - dziś nierozerwalnie związane z krajobrazem miasta. Na początku XX w. ogród i cały kwartał Pól Marsowych nabrał obecnego wyglądu. Dziedzictwo urbanistyczne paryskich wystaw to oś kompozycyjno-widokowa Ecole Militaire - Champ de Mars - Palais de Chaillot. Dziś reprezentacyjna ogrodowa przestrzeń publiczna ukształtowana à la francaise pod kierunkiem J.C. Formigé. Doskonale wpisuje się W strukturę urbanistyczną miasta, kontynuując tradycje wielkich osi paryskich. Jej znaczenie wzmacnia niesłabnąca atrakcyjność i popularność królującej na Paryżem wieży Eiffla, oryginalnej bramy i wizytówki paryskich wystaw. [4] [5] [6] [7] [8] [9] [10] [11] [12] [13] [14] [15] [24]

CHICAGO 1893, 1933. Wystawę światową w Chicago w 1893 r. zlokalizowano na nabrzeżu jeziora Michigan na rozległych terenach parkowych, zaprojektowanych 20 lat wcześniej przez spółkę Olmsted \& Vaux, znaną już z projektu Central Park na Manhattanie. Wystawa stanowiła silny impuls - doładowanie energii, dla realizacji zespołu trzech parków Jackson Park, Midway Plaisance i Washington Park, których budowa utknęła wcześniej w martwym punkcie ${ }^{3}$ [16] [17]. To właśnie dzięki wystawie parki te powstały.

Wystawa Kolumbijska 1893 r. zadziwiła świat rozmachem oraz nadzwyczaj spójną estetycznie i stylistycznie koncepcją urządzenia terenów wystawowych. Wyczarowany na wybrzeżu jeziora Michigan, na terenie dzisiejszego Jackson Park, neoklasycystyczny świat marzeń - Białe Miasto (White City) - z jednolitą bielą monumentalnych Wielkich Budowli (Grand Buildings) ${ }^{4}$, wyrafinowaną oprawą rzeźbiarską i krajobrazowo projektowanymi terenami ogrodowymi - dzieło współpracy architektów pod kierownictwem D.H. Burnhama $^{5}$ i J.W. Root'a oraz architektów krajobrazu F.L. Olmsteda ${ }^{6}$ i H.S. Lodmana - stanowił dla miejscowej publiczności atrakcyjną wizualnie antytezę dla ponurego środowiska urbanistycznego ówczesnych amerykańskich miast. W łączniku między dwoma parkami Midway Plaisance - zlokalizowano strefę rozrywki ze słynnym kołem Ferrisa, ikoną wystawy, urządzeniem posiadającym niezliczone naśladownictwa w parkach rozrywki na całym świecie. [6] [8] [15] [16]

3 Plany realizacji zespołu trzech parków, kształtujących system zieleni miasta, łączących nabrzeża jeziora Michigan z wewnątrzmiejskimi parkami systemem lagun i kanałów wodnych, według projektów F.L. Olmsteda i C. Vaux zostały przerwane z powodu pożaru oraz ze względów finansowych. Teren pozostał nieciekawym kawałkiem piaszczystego gruntu, porośniętym chaotycznie drzewami i krzewami. Po wyborze Chicago na gospodarza wystawy światowej w 1890 r., F.L. Olmsted i H. Lodman, rozważający miejsca lokalizacji wystawy, dostrzegli w tych terenach ogromny potencjał, do czego przekonali organizatorów oraz architekta wystawy D.H. Burnhama. [16] [17]

4 Nowością było wykorzystanie w architekturze obiektów wystawowych praktycznej i bardzo efektownej techniki budowlanej - gipsowych tynków na drewnianych lub stalowych szkieletach. [6] [8] [15]

5 Daniel H. Burnham, chicagowski architekt, doskonale dobrał najlepszych architektów, inżynierów i rzeźbiarzy by zrealizować wielkie plany wystawy. Jego menadżerskie i planistyczne umiejętności zadecydowały w dużej mierze o sukcesie Wystawy Kolumbijskiej. Znana jest jego maksyma: „Nie róbcie małych planów, one nie mają magii mieszania ludzkiej krwi”. [16]

6 Frederick Law Olmsted, architekt krajobrazu i pomysłodawca generalnego planu Wystawy Kolumbijskiej, opracował studia i projekty wielu parków, lasów, ogrodów botanicznych i zoologicznych. Najważniejsze z nich to: tereny publiczne w Washington, D.C., Central Park w Nowym Jorku oraz parki publiczne w Bostonie, Montrealu i Chicago. [16] 
Jako spuściznę Wystawy Kolumbijskiej 1893 r., ale także kolejnej zorganizowanej tutaj wystawy Century of Progress Exposition 1933 r. [6] [7] [8] [18], Chicago otrzymało zespół trzech, powiązanych ze sobą parków Jackson Park, Midway Plaisance i Washington Park, kształtujących system terenów zieleni miasta, pełniących ważne funkcje ekosystemowe, ale też reprezentacyjne, $\mathrm{z}$ odwołującymi się do wystaw obiektami i ogrodami o charakterze kommemoratywnym. W Jackson Park, od 1972 r. na liście National Register of Historic Places, pozostałością Wystawy Kolumbijskiej jest Wooded Island z ogrodem japońskim Osaka Garden z Ho-O Den (świątynia Phoenixa) jako pawilonem Japonii zaprojektowanym przez F.L. Olmsteda na wystawę 1893 r. Ogród poważnie zniszczony w czasie II wojny światowej, odrestaurowany i przywrócony do dawnej świetności, uznany przez American Institute of Architects (AIA) za jedno ze „150 great places in Illinois”, dziś jest ulubionym miejscem odpoczynku mieszkańców Chicago [16] [19] [20]. Pas Midway Plaisance w 1926 r. stał się parkową osią kampusu University of Chicago, ramowaną budynkami uniwersyteckimi po obu stronach. W 1999 r. biuro architektury krajobrazu OLIN opracowało nowy master plan dla Midway Plaisance, stanowiący swoisty hołd dla oryginalnych założeń F.L. Olmsteda. Jest on na bieżąco implementowany [21] [22]. Parki doposażono o szereg funkcji sportowych, rekreacyjnych, kulturalnych, edukacyjnych, itd. służących mieszkańcom Chicago ${ }^{7}$ [19] [20]. Imponująca sceneria White City została zniszczona w pożarze. Do dzisiaj w Chicago pozostały tylko dwa obiekty, będące świadkami i symbolami Wystawy Kolumbijskiej - Pałac Sztuk Pięknych, ponownie otwarty jako Muzeum Nauki i Przemysłu na wystawę w 1933 r. i działający jako takie do dzisiaj oraz Statua Republiki, trzykrotnie zmniejszona replika oryginalnej Republiki autorstwa D.C. French'a, niegdyś głównego akcentu rzeźbiarskiego Court of Honor ${ }^{8}$ [7] [16] [23] [24].

Wystawa Kolumbijska miała ogromny przestrzenny i wizualny wpływ nie tylko na samo miasto, ale zadziałała ponadlokalnie, i to w skali całego kraju. Wywarła znaczący, ale też kontrowersyjny wpływ na trendy w amerykańskiej architekturze i urbanistyce w następnym półwieczu [16]. Zaprezentowany tam neoklasycyzm - pokrywane gipsowymi tynkami białe fasady w klasycystycznym stylu, w oderwaniu od współczesnych trendów, widocznych w najbardziej zaawansowanych projektach i rosnących w górę wysokościowcach w Chicago - stał się de facto narodowym stylem, realizowanym w niezliczonych budynkach rządowych i użyteczności publicznej w całych Stanach Zjednoczonych [6] [8] [15]. Zauroczona wizerunkiem wystawy poetka Katharine Lee Bates napisała America the Beautiful, spacery w White City stały się dla L. Franka Bauma inspiracją dla słynnego Emerald City [16] - to tylko wybrane przykłady nadzwyczajnego oddziaływania scenerii miasteczka ekspozycyjnego na wyobraźnię i kształtowanie gustów zwiedzających. Alabastrowe miasto - White City, obudziło publiczne zainteresowanie estetyką miast, co przerodziło się w ruch społeczny na rzecz upięknienia miast - City Beautiful Movement. Efekt to opracowane przez Daniela Burnhama we współpracy z Frederickiem L. Olmstedem i kilkoma innymi architektami Great Buildings, plany City Beautiful dla m.in. Cleveland, Washington, D.C., San Francisco, a także dla Chicago [6] [8] [15] [16]. Przestronne, krajobrazowo zaprojektowane tereny powiązane szerokimi zielonymi bulwarami, przełamujące, a jednocześnie scalające rusztowe układy wielu amerykańskich miast, stanowią dalekosiężne dziedzictwo Wystawy Kolumbijskiej. Synergiczna sieć powiązań architektonicznych i urbanistycznych - której zaczątkiem były tereny wystawy światowej - rozprze-

7 W Jackson Park w 1899 r. otwarto pierwsze publiczne pole golfowe na Środkowym Zachodzie, które działa do dzisiaj. [20] [21]

8 Innymi architektonicznymi pozostałościami wystawy, obecnie poza Chicago, są: pawilon norweski, zwany Little Norway, umieszczony w muzeum w Blue Mounds, Wisconsin oraz Maine State Building przeniesiony do Poland Springs. [16] [23] [24] 
strzeniła się i objęła swoim zakresem niemal cały kraj, stając się wzorcem kształtowania 'Pięknych Miast' - City Beautiful! [4] [6] [7] [8] [15] [16] [17] [18] [19] [20] [21] [22] [23] [24]

BARCELONA 1888, 1929. Znaczące i trwałe ślady w krajobrazie i przestrzeni miasta pozostawiły wystawy światowe w Barcelonie, gdzie - podobnie jak w Paryżu - starano się wiązać tereny wystaw zarówno między sobą, jak i z miastem poprzez osie - aleje, węzły place oraz wyróżniki przestrzenne (landmarki) - akcenty rzeźbiarskie.

Wystawa 1888 r. odbywała się na terenie parku Ciutadella, tworzonym od 1871 r. wg projektu Josepa Fontseré na terenie pofortecznym dawnej cytadeli ${ }^{9}$ [25] [26] [27]. Znaczące było usytuowanie parku w strukturze urbanistycznej Barcelony - na styku pomiędzy organiczną tkanką średniowieczną, a regularną siatką XIX-wiecznego miasta, realizowanego według planu Ildefonso Cerdy. W scenerię swobodnie kształtowanego krajobrazu parkowego wkomponowano obiekty wystawy 1888 r., od strony architektonicznej nadzorowanej przez Eliesa Regenta, pod względem artystycznym odzwierciedlające ducha modernisme - katalońskiej odmiany secesji ${ }^{10}$ [25] [28] [29]. Obecnie głównymi atrakcjami parku są pozostałości wystawy 1888 r. - cieniarnia L'Umbracle i cieplarnia L'Hivernacle [25] [26] [30] oraz jedno z najbardziej emblematycznych dzieł modernisme, inspirowany baśniowymi motywami orientu, budynek restauracji Castell dels Tres Dragons (proj. L. Domènech i Montaner $)^{11}$ [25] [26]. Do terenów wystawowych włączono poprzedzającą park, ramowaną rzeźbami ${ }^{12}$ [25] [27] i ozdobnymi latarniami, promenadę Saló de Sant Joan $^{13}$ (proj. P. Falqués). Bramą do wystawy był oryginalny ceglany łuk triumfalny (proj. J. Vilaseca i Casanoves) z dekoracją reliefową wykonaną przez katalońskich rzeźbiarzy doby modernisme ${ }^{14}$ [25] [27] [30] [31]. Obiekty te kształtują do dzisiaj jedną z najbardziej

9 Park Ciutadella znany jest także z neobarokowej fontanny La Cascada wzniesionej w 1878 r. jednego z pierwszych dzieł A. Gaudí'ego zaprojektowanej wspólnie z Fontseré.

${ }^{10}$ Styl modernisme, przejawiający się w architekturze, rzeźbie, malarstwie i sztuce ogrodowej od końca XIX w. do lat 30. XX w., wykształcił oryginalne lokalne formy i detale, stanowiące o niepowtarzalnym wyrazie obiektów architektonicznych i ogrodowych realizowanych w owym czasie w Barcelonie. Początkowo niechętnie odbierany, długo traktowany jako przejaw złego gustu, stał się z czasem synonimem wyrafinowanej estetycznie i pełnej fantazji kultury architektonicznej Barcelony. Odwołujący się do motywów narodowych i ukrytych nacjonalistycznych znaczeń, stanowił część szerszego zjawiska, jakim był kataloński Renaixença, nawiązujący do historycznych stylów i rzemiosła, czerpiący inspiracje z katalońskiego gotyku i tradycyjnego kowalstwa artystycznego, sięgający do ornamentalnych wzorców arabskiej Hiszpanii. Rozwinął nowe koncepcje architekto-niczne w oparciu o naturalne lokalne materiały, kamień i ceramikę oraz ornamentykę wykorzystującą giętką linię i formy organiczne, żywą kolorystykę i symbolikę inspirowaną światem natury. Zasygnalizowane w parku Ciutadella elementy stylu modernisme osiągnęły swoją pełną i nadzwyczaj oryginalną postać w słynnym parku Güell (proj. Antoni Gaudí, 1900-1914). [25] [28] [29]

11 Castell dels Tres Dragons (Zamek Trzech Smoków) to średniowieczny kaprys, wzorowany na budynku Llotja w Walencji, stylizowany na baśniowy zamek z arabskimi motywami, z wieżami zwieńczonymi ceramicznymi koronami. W architekturze obiektu wykorzystano materiały charakterystyczne dla barcelońskiego modernisme. Surowe cegły wypełniają metalowy szkielet, a całość dopełniają wymyślne detale z kutego żelaza. [25] [26]

12 W 1883 r. Saló de Sant Joan wyposażono w serię rzeźb, upamiętniających historyczne postacie, jak: Guifré el Pelós (aut. V. Vallmitjana), Roger de Llúria (aut. J. Reynés), Bernat Desclot (aut. M. Fuxà), Rafael Casanova (aut. R. Nobas), Ramon Berenguer I (aut. J. Llimona), sędzia Pere Albert (aut. A. Vilanova), malarz Antoni Vila-domat (aut. T. Tasso), architekt Jaume Fabre (aut. P. Carbonell). [25] [27]

13 Obecna nazwa Saló de Sant Joan to Passeig de Lluís Companys i Passeig de Sant Joan.

14 Oryginalna architektura Arc de Triomf miast nawiązania do antyku i użycia kamienia, odwołuje się do tradycji islamskich. Głównym materiałem jest ulubiona przez barcelońskich modernistów cegła. Dekorację rzeźbiarską łuku, w postaci figur i motywów z ceramiki oraz wieńczących bulwiastych kopuł, wykonali katalońscy artyści: J. Llimona, J. Reynés, T. Tasso i A. Vilanova. [25] [27] [30] [31] 
reprezentacyjnych przestrzeni publicznych miasta Wyróżniającym się akcentem w krajobrazie Barcelony, wzniesionym jako symbol wystawy 1888 r., jest pomnik Krzysztofa Kolumba (aut. G. Buïgas, R. Atché) [25] [26] [27]. Posąg usytuowano w strategicznym punkcie - na przecięciu ważnych urbanistycznych osi: słynnej barcelońskiej Rambli, Passeig de Colom - łączącej z parkiem Ciutadella, oraz Avenida del Parallel, prowadzącej do stóp góry Montjuic - miejsca organizacji kolejnej wystawy w $1929 \mathrm{r}$.

Wyniesiona na wysokiej kolumnie postać odkrywcy Nowego Świata, majestatycznie góruje nad zabudowaniami nabrzeża i starego portu, pełniąc rolę nie tylko świadka wystawy 1888 r., ale symbolu o szerszym zasięgu - ikony Barcelony. Sam park Ciutadella, później doposażony jeszcze o inne atrakcje, jak: ZOO, Muzeum Sztuki Nowoczesnej i Muzeum Zoologii oraz siedziba Parlamentu Katalonii (w dawnym arsenale twierdzy), stanowi obecnie lubiany przez mieszkańców i turystów największy urządzony teren zieleni W centrum miasta [25] [26] [27] [28] [29] [30] [31].

Na miejsce wystawy 1929 r. wybrano szczególnie eksponowaną w krajobrazie lokalizację - wzgórze Montjuïc - dominantę topograficzną miasta, o bogatej historii, ze znajdującymi się tam ważnymi obiektami architektonicznymi i dotychczasowymi elementami zagospodarowania $^{15}$ [25] [26]. Wystawę zorganizowano równolegle z Igrzyskami Olimpijskimi, a powiązanie tych dwóch wydarzeń we wspólnej lokalizacji ${ }^{16}[6]$, podnosiło ich rangę i stanowiło dodatkowy zastrzyk energii. Kompozycję głównych terenów wystawowych (proj. J. Puig i Cadafalch) oparto na monumentalnej osi Plac Espanya - Avinguda de la Reina Maria Cristina - Palacio Nacional - Stadion Olimpijski, z racji amfiteatralnego usytuowania na stoku dobitnie eksponowanej w krajobrazie. Oś rozpoczynała się na położonym u stóp Montjuïc rondzie Plaça d'Espanya, w którego centrum usytuowano monumentalną grupę rzeźbiarską oraz figury symbolizujące hiszpańskie rzeki i symbole zdrowia i obfitości. Następnie oś - przekraczając symboliczną bramę utworzoną przez dwie bliźniacze 47-metrowe wieże - zaczynała wznosić się ku szczytowi wzgórza szeroką promenadą Avinguda de la Reina Maria Cristina, ramowaną monumentalnymi pawilonami ekspozycyjnymi, wyposażoną w rzeźbiarsko formowane schody, fontanny ze słynną, działającą do dzisiaj La Font Màgica ${ }^{17}$ [26], ozdobne balustrady, latarnie, liczne rzeźby i posągi ${ }^{18}$ [25]

${ }^{15}$ Na Montjuïc odkryto ślady osadnictwa pierwszych mieszkańców terenów dzisiejszej Barcelony Celtyberów. Nazwa wzgórza oznacza Żydowską Górę i pochodzi od społeczności żydowskiej, która niegdyś osiedlała się tutaj. W XVIII w. na szczycie ulokowano twierdzę Castell de Montjuïc - mroczne więzienie z czasów represji frankistowskich. Na wzgórzu położona jest majestatyczna nekropolia Cementiri del Sud-Oest (Cementiri Nou), oddana do użytku w 1883 r. Masywne kamienne grobowce wieńczące szczyt wzgórza kształtują niesamowity krajobraz. [25] [26]

16 Łączenie wystaw światowych z olimpiadami nie jest odosobnionym przypadkiem i wpisuje się w historię organizacji tych wydarzeń. [6]

17 Magiczna Fontanna (La Font Màgica) (proj. C. Buïgas) to usytuowana przed Palau Nacional monumentalna, iluminowana fontanna, stanowiąca jedną z głównych atrakcji terenów wystawy $1929 \mathrm{r}$. Została odrestaurowana na czas Olimpiady w 1992 r. by do dziś zachwycać widzów niezwykle ekspresyjnymi spektaklami z animacją światła i wody. [26]

18 Wystawa 1929 r. w Barcelonie to okres apoteozy rzeźby, która wydatnie „zasiliła” urządzane w owym czasie place miejskie i przestrzenie parkowe. Najbardziej znaczącym osiągnięciem było Sant Jordi nu (J. Llimona 1924-1929). Do dzisiaj podziwiać możemy monumentalną grupę rzeźbiarską ustawioną na Plaça d'Espanya (J.M. Jujol 1929) oraz figury symbolizujące Ebro, Tag i Guadalquivir (M. Blai, Lluci, M. Oslé, F. Llobet) i równolegle do nich symbole zdrowia i obfitości. Wyróżniającą rzeźbą związaną z Wystawą jest klasyczna figura kobieca Matí (G. Kolbe 1927) w Pawilonie Niemieckim M. van der Rohe. Rzeźba doby wystawy 1929 r. pod względem artystycznym odwoływała się do monumentalnych nurtów pomiędzy Barokiem a Noucentisme - katalońskim ruchem artystycznym z pocz. XX w., będącym w opozycji do modernizmu i nawołującym do powrotu do „,apollińskiego klasycyzmu”. Tendencja do monumentalizmu widoczna jest szczególnie w najbardziej emblematycznych symbolach wystawy: 
[27] [31]. Główna aleja uzyskała swoje monumentalne zwieńczenie w najbardziej spektakularnym obiekcie wystawy Pałacu Narodowym (Palau Nacional). Obiekt ten, oryginalnie zaprojektowany jako secesyjny (proj. J. Puig i Cadafalch) został na czas wystawy 1929 r. ze względów propagandowych przebudowany w duchu neoklasycyzmu i neobaroku, uzyskując pretensjonalny, bombastyczny wygląd. Mimo pierwotnie planowanej rozbiórki pałac pozostał do dzisiaj i jest siedzibą Katalońskiego Muzeum Narodowego Sztuk Pięknych [25] [26]. Reprezentacyjną oś terenów wystawowych między Plaça d'Espanya, a Palau Nacional, dopełniało jeszcze wiele innych obiektów, rozmieszczonych na zboczach Montjuïc w otoczeniu parkowej zieleni. Wśród nich - wzniesiony dla celów równolegle rozgrywanej Olimpiady, stadion o eklektycznej formie, który został zmodernizowany na Igrzyska Olimpijskie w 1992 r. i funkcjonuje do dzisiaj w ramach szerszego i doposażonego o dodatkowe obiekty sportowe, parku olimpijskiego Anella Olimpica, jako Estadi Olímpic [26] oraz amfiteatr Teatre Grec, wykorzystywany do plenerowych spektakli i wydarzeń kulturalnych. Popularnym, ale i wywołującym wiele kontrowersji, obiektem powystawowym, okazała się tzw. Wioska Hiszpańska (Poble Espanyol) (proj. F. Folgera, R. Reventós), stanowiąca kiczowaty konglomerat replik zabytkowych budowli i charakterystycznych form zabudowy i krajobrazu Hiszpanii [6] [7] [26] [32], usytuowana w cieniu drzew porastających zbocza Montjuïc. Po zamknięciu wystawy nieco podupadła, ale po przeprowadzonej rewaloryzacji przed Olimpiadą 1992 r. (proj. A. Arribas, X. Mariscal), która poszerzyła ofertę turystyczną i rozrywkową, ponownie stała się modną destynacją. Obiektem, którego powystawowa kariera, odbiła się szczególnym echem, zwłaszcza w profesjonalnych kręgach architektury, był wzniesiony na wystawę 1929 r. Pawilon Niemiecki (proj. Mies van der Rohe), ikona architektury modernistycznej ${ }^{19}$ [6] [7] [8] [12] [24] [26] [27] [31] [33] [34] [35] [36]. Purystyczna forma pawilonu, stanowiąca przestrzenną grę lśniących tafli szkła, marmuru, onyksu, trawertynu i wody, kontrastowo odbijała się od bogato uformowanego, eklektycznego tła terenów wystawowych. Rozebrany po zakończeniu wystawy Pavelló Mies van der Rohe ${ }^{20}$ [36] został zrekonstruowany w 1986 r. i nadal odcina się minimalistyczną formą na tle wybujałego formalnie krajobrazu głównej osi terenów wystawy 1929 r. Pawilon Van der Rohe to symboliczny początek ery nowoczesnej architektury, wzorzec dla późniejszych interpretacji modernizmu czy minimalizmu, którego rola w historii architektury może być porównywana do Pałacu Kryształowego z Wystawy Londyńskiej (1851) czy paryskiej wieży Eiffla (1889). To doskonała ilustracja poszerzania i przekraczania granic architektury i jej społecznego odbioru, a także znaczenia wystaw światowych na tej drodze. Dodatkową lokalizacją, stanowiącą ważne ogniwo w sieci powiązań pomiędzy obiektami wystawowymi był Plac Catalunya zrealizowany w $1927 \mathrm{r}$. według koncepcji F. de Paula Nebot z niewielką świątynią, centralną kolumnadą oraz

pałacach Alphonso XIII i Victorii Eugenii, Magicznej Fontannie oraz Pałacu Narodowym. W opozycji do tej konwencji rzeźbiarskiej, ocenianej przez krytykę jako mierny pastisz form klasycznych, swój zauważalny wkład w rzeźbiarską oprawę przestrzeni publicznych miasta wnieśli P. Gargallo (pomnik Lleó Fontova w parku Ciutadella, Iscle Soler na Plaça de Sant Agustí, Aurigues i Genets wieńczące stadion na Montjuïc) i J. Gonzàlez, określani pionierami poszukiwań nowych materiałów i środków wyrazu w rzeźbie. [25] [27] [31]

19 W czysto symbolicznej formie obiektu doszukiwano się śladów stylistyki F.L. Wrighta, de Stijlu i tradycji „Schinkelschüle”, dostrzegano echa dadaistyczne a nawet antyracjonalistyczne. Obiekt w pełni egzemplifikował modernistyczne pojęcia „wolnego planu” i „otwartej przestrzeni”. Nowość i bezprecedensowość w sposobie kształtowania przestrzeni architektonicznej manifestowały się tutaj w postaci niezakłóconej klasycznymi podziałami ciągłości przestrzeni, w której wzrok widza może poprzez szklane ściany przenikać z wnętrza do wnętrza. [12] [24] [26] [27] [31] [33] [34] [35] [36]

${ }^{20} \mathrm{~W}$ znanej książce $S, M, L, X L$ w tekście ,Less is More” Rem Koolhaas bada zawiłe losy awangardowego Pawilonu Niemieckiego z wystawy 1929 r. [36] 
dekoracyjnymi detalami, jak monumentalna fontanna, seria rzeźb z kamienia i brązu, autorstwa wiodących rzeźbiarzy tego okresu (F. Marès, E. Arnau, V. Navarro, P. Gargallo, J. Llimona i J. Viladomat, J.M. Subirachs) oraz słynna marmurowa Deessa (aut. J. Clarà, 1909), stanowiąca do dzisiaj piękny akcent odbijający się w lustrze rozległej sadzawki [25] [27] [31].

Wkład wystaw 1888 i 1929 r. w kształtowanie krajobrazu Barcelony jest ogromny. Wzbogaciły miasto $\mathrm{w}$ istotne obiekty użyteczności publicznej oraz reprezentacyjne przestrzenie publiczne, zarówno place, aleje i pasaże, jak i tereny parkowe i akcenty rzeźbiarskie. Połączone synergiczną siecią urbanistycznych i krajobrazowych powiązań, stanowią do dzisiaj wyróżniające się dominanty i landmarki w strukturze miasta, niosące wiele symbolicznych znaczeń i budujące specyficzny genius loci miasta [4] [6] [7] [8] [24] [25] [26] [27] [28] [29] [30] [31] [32] [33] [34] [35] [36].

NOWY JORK 1853, 1939, 1964. Pierwsza wystawa w Nowym Jorku w 1853 r. była odpowiedzią Amerykanów na Wielką Wystawę Londyńską (1851), która rozbudziła manhattańskie ambicje. Miasto sięgało wówczas zaledwie do 42 ulicy, a poza Wall Street przypominało wieś z pojedynczo rozsianymi domami. Stąd też wzniesione na wystawę dwie imponujące konstrukcje - budowla zwieńczona na wzór londyńskiego Pałacu Kryształowego gigantyczną kopułą i niemal stumetrowej wysokości wieża Latting Observatory, którą ,jeśli pominąć wieżę Babel, można (...) nazwać pierwszym drapaczem chmur w historii" ${ }^{21}$ [37] - wyraźnie zdominowały krajobraz wyspy i wprowadziły swoją skalą całkiem nową jakość. Nowojorski Pałac Kryształowy spłonął w 1858 r. [6] [8], wieża została rozebrana, ale wyjazd windą na jej szczyt pozwolił mieszkańcom Manhattanu obejrzeć go z góry, a co za tym idzie zdać sobie sprawę z ograniczeń wynikających z tego położenia. Według R. Koolhaasa „Oglądanie z góry to powracający motyw manhattanizmu. Nabywana pod jego wpływem geograficzna samoświadomość powoduje eksplozję zbiorowej energii, a zarazem przekłada się na wyznaczanie megalomańskich celów" [37]. Dominującym kierunkiem urbanizacji wyspy stało się pięcie ku górze przy minimalizowaniu powierzchni zajmowanego terenu. Na ile tendencja ta wynikała $\mathrm{z}$ refleksji po obejrzeniu panoramy miasta z wieży wzniesionej na wystawę 1853 r., trudno ocenić, ale z pewnością był to jeden z przełomowych momentów w kształtowaniu przestrzeni Manhattanu. Śladem wystawy 1853 r. jest zajmujący dziś dwa bloki zabudowy Bryant Park [8] - dowód parkotwórczej roli wystaw.

Następnym dwóm wystawom, zorganizowanym już w XX wieku, Nowy Jork zawdzięcza powstanie parku o o wiele większej skali i znaczeniu w strukturze miasta. Wystawa 1939 r. odbyła się nie na Manhattanie, ale na bagnistych terenach miejskiego wysypiska śmieci Corona Dumps w dzielnicy Queens, opisanych jako „dolina kurzów” w Wielkim Gatsby'm F.S. Fitzgeralda. Po nowojorskich wystawach tereny te zaczęto określać Flushing Meadows. Ta ryzykowna decyzja organizatorów, wymagająca uporządkowania zdegradowanego, podmokłego terenu, zmiany przebiegu rzeki, wyposażenia obszaru w 62 mile nowych dróg, infrastrukturę techniczną, 200 budynków, 10000 drzew, 2 miliony krzewów - zakończyła się wielkim sukcesem. Powstał drugi co do wielkości teren wystawowy w świecie, na którym zorganizowano dwie wielkie ekspozycje w 1939 i 1964 r. [6] [8] [37] [38] [39] Nowatorska była koncepcja miasteczka Expo - według Koolhaasa pomyślana jako ,anty-Manhattan” [37] - swoista antyteza najeżonego wieżowcami Manhattanu z pawilonami wystawowymi, mieszczącymi się w jednokondygnacyjnych halach bez okien, z wielkimi połaciami pustych ścian, wypełnionych artystycznymi muralami i płaskorzeźbami [6] [7] [8] [15] [37]. Niskie budynki zapewniły powiązania widokowe z rysującym się

${ }^{21}$ [za:] Official Guidebook, New York World's Fair, New York: Exposition Publications [37] 
w oddali skyline Manhattanu. Kompozycja terenów wystawowych została klasycznie rozplanowana a'la paryskie Pola Marsowe z osiami zbiegającymi się w Centrum Tematycznym z zespołem symbolicznych struktur - wysoką na $186 \mathrm{~m}$ iglicą Trylon i towarzyszącą jej kulą o średnicy $55 \mathrm{~m}$ - Perisphere (proj. W.K. Harrison, J.A. Fouilhoux) ${ }^{22}$ [6] [8] [15] [33] [38] [40]. Zdaniem Koolhaasa - Kula i Iglica to bezpośrednie odniesienie do dwóch przeciwstawnych form, które zdefiniowały architekturę Manhattanu. Odseparowanie ich od siebie wyznacza symbolicznie koniec manhattanizmu [37]. Projekcją głównego motta wystawy 1939 r. „Budowanie Świata Jutra” były futurystyczne pokazy miast przyszłości - dioramy 'Democracity' i 'City of the Future' (proj. H. Dreyfuss) mieszczące się w Perysferze, a także 'Futurama' w pawilonie General Motors (proj. N.B. Geddes). 'Democracity' - wyidealizowana wizja milionowej „Metropolii Wieku Maszyny”, w której wokół stupiętrowej wieży rozciąga się ,doskonale zharmonizowane „miasto-ogród jutra"23 [37] pełne światła, powietrza i zieleni, wzorowane na „Mieście Promienistym” Corbusiera. Kolejny dowód na to, że Manhattan pełen ciasno stłoczonych wież od 1939 r. odchodzi już w przeszłość [6] [7] [8] [15] [37] [38] [40]. To następna wywiedziona z wystaw światowych wskazówka - po City Beautiful, zainaugurowanym w White City w Chicago w 1893 r. - jak kształtować krajobraz amerykańskich miast. Dalekosiężne dziedzictwo wystawy nowojorskiej 1939 r. Po Expo 1939 r. pozostał ogromny, uzbrojony teren, przygotowany do organizacji kolejnych wydarzeń. Większość obiektów została rozebrana i w zasadzie jedynym architektonicznym śladem wystawy pozostał klasycyzujący Pawilon Miasta Nowy Jork (proj. A. Embury II), który od 1972 r. funkcjonuje jako Queens Museum of Art [8] [38].

Kolejna zorganizowana na Flushing Meadows wystawa 1964 r. odziedziczyła plan i infrastrukturę po wystawie 1939 r., tylko pawilony tym razem zaaranżowane w zespołach tematycznych były inaczej rozmieszczone. W tym sensie plan przypominał nieco projekt Fréderica Le Play dla wystawy paryskiej 1867 r. Symbolem wystawy była po raz kolejny kula - wysoka na 12 kondygnacji, konstrukcja ze stali nierdzewnej przedstawiająca Ziemię z zarysami kontynentów - Unisphere (proj. Peter Muller-Munk Associates, architektura krajobrazu G. Clarke), ustawiona na tych samych fundamentach, które kiedyś stanowiły podstawę Perisphere z 1939 r. „Znów Kula, lecz ulotna i przezroczysta, pozbawiona zawartości. Kontynenty desperacko lgną do ścierwa manhattanizmu jak przypalone kotlety do patelni" - tak skomentował to nieudane dzieło R. Koolhas [37]. Niemniej jednak to ta właśnie kula, ustawiona w centrum owalnego basenu stanowi główną atrakcję dzisiejszego parku Flushing Meadows, wskazującą wystawy światowe jako genezę jego powstania. Wśród parkowej zieleni wyróżnia się również dawny Pawilon Nowego Jorku (proj. P. Johnson, R. Foster, konstrukcja L. Zetlin), znany pod nazwą Namiot Jutra z gigantycznym owalnym dachem, zawieszonym na 16 pustych betonowych kolumnach, z górującymi futurystycznymi wieżami widokowymi - w ostatnich latach odnowiony i przywrócony do dawnej świetności. Być może najbardziej trwałym dziedzictwem wystawy 1964 r. jest Panorama Miasta Nowy Jork, wielkoskalowy model miasta, wystawiany oryginalnie w Pawilonie Nowego Jorku, obecnie na bieżąco aktualizowany znajduje się w Queens Museum of Art, pozostałości wystawy 1939 r. Impuls, jaki dały nowojorskie wystawy światowe, sprawił, że niegdyś pozbawiony wartości, zdegradowany teren dawnego śmietniska stał się aktywnie użytkowanym na wiele sposobów parkiem Flushing Meadows, drugim

22 Rzeźbiarskie, abstrakcyjne, geometrycznej formy Trylonu i Perysfery wg A. Stefańskiej były inspirowane XVIII-wiecznymi projektami Boullé i Ledoux, pracami Bauhausu i fantazjami konstruktywisty J. Czernichowa z lat 20. XX w. [za:] A. Stefańska, Udziat artystów polskich na Wystawie Światowej w Nowym Jorku, praca magisterska pod kier. T. Gryglewicza, UJ 1999, mps, s. 11 [38]

23 [za:] Official Guidebook, New York World's Fair, New York: Exposition Publications [37] 
co do wielkości w Nowym Jorku, stanowiącym istotne ogniwo w systemie terenów zieleni miasta z kilkoma wyróżniającymi się artefaktami architektonicznymi - świadkami wystaw 1939 i 1964 r. [4] [6] [7] [8] [15] [37] [41] [42]

SEATTLE 1909, 1962. Seattle, które stało się znane całemu światu po słynnym Expo 1962 r., miało już wcześniejsze doświadczenia w organizowaniu wielkich wystaw. W 1909 r. było gospodarzem Alaska - Yukon - Pacific - Exposition. Tereny wystawy rozplanowano zgodnie z ideami City Beautiful, których kolebką była Wystawa Chicagowska 1893 r., a które były implementowane w praktycznym wymiarze w przestrzeni miasta za sprawą firmy Olmsted Brothers / Brookline Massachusetts Landscape Architecture, zaproszonej w 1903 r. przez władze miasta do projektu systemu zieleni miejskiej. Powstały wówczas zaczątki, realizowanego przez kolejne stulecie, systemu parków, terenów zieleni osiedlowej i zielonych bulwarów. W projekcie terenów wystawowych, nadzorowanym przez Johna C. Olmsteda i prowadzonym przez James'a F. Dawsona z Olmsted Brothers, wykorzystano dominantę topograficzną miasta górę Mount Rainier jako zamknięcie widokowe głównej osi całego założenia - Rainier Vista, zakomponowanej wzdłuż długiego basenu z fontannami, ramowanej budowlami w neoklasycznym stylu. Ten układ kompozycyjny, a także towarzysząca infrastruktura techniczna i zielona wystawy 1909 r., stały się podstawową kanwą układu urbanistycznego utworzonego tu kampusu uniwersyteckiego University of Washington. Rainier Vista i fontanna Drumheller stanowią dzisiaj główny akcent kwartału Science Quadrangle. Dziedzictwem architektonicznym wystawy są dwie zachowane na terenie uniwersyteckim budowle: Architecture Hall (podczas wystawy Fine Arts Palace, proj. firma J.G. Howarda, Howard and Galloway) i Cunningham Hall (podczas wystawy Women's Building) [43] [44] [45].

Century 21 Exposition, która do historii wystaw światowych przeszła również pod nazwą 1962 Seattle World's Fair, zmieniła obraz Seattle - do tej pory ambitnego, ale jednak dość peryferyjnego miasta - w prężnie rozwijający się i nowoczesny ośrodek zachodniego wybrzeża USA. Przyczyniła się do tego futurystyczna narracja wystawy, bazująca na podstawowych idiomach - nauce i przestrzeni kosmicznej oraz kreacji świata jutra XXI wieku. By nadać materialny kształt tym ideom, główny architekt Expo Paul Thiry stworzył na terenach wystawowych futurystyczne miasto [15] [44], rozplanowane nie według dotychczas zasad Beaux-Arts czy City Beautiful z szerokimi alejami, ramowanymi monumentalnymi budowlami, a ze swobodnie rozproszonymi na całym terenie ekspresyjnymi obiektami o futurystycznej formie. Najdobitniejszym ikonicznym wcieleniem nauki jako idiomu postępu była symboliczna struktura Kosmiczna Iglica (Space Needdle) (proj. John Graham). Ekstremalnie popularna, wysoka na 600 stóp wieża widokowa z obracającą się restauracją, zlokalizowaną w podobnej do spodka platformie obserwacyjnej, stała się najbardziej wyrazistym landmarkiem Seattle, reprezentującym nie tylko miasto, lecz również wzrost i prosperity, najbardziej ekspresyjnym amerykańskim monumentem związanym z tradycją wystaw, o znaczeniu i symbolice porównywanymi z paryską wieżą Eiffla. Futurystyczną stylistykę prezentował pawilon Washington Square Colliseum, (proj. Paul Thiry), w którym ekspresyjne betonowe przypory podtrzymywały łamany kwadratowy dach. Pawilon Nauki USA (United States Science Pavilion) (proj. Minoru Yamasaki) tworzył zespół sześciu budynków ze znajdującym się między nimi placem z pięcioma rzeźbiarskimi, ażurowymi, aluminiowymi strukturami tzw. gotyckimi wieżami [8] [15]. Wyniesiona ponad poziom terenu kolejka monorail przywoziła zwiedzających na tereny wystawowe z centrum miasta, a dwa pociągi na gumowych oponach woziły pasażerów na 90sekundową wycieczkę. Aby zrealizować ten futurystyczny scenariusz wybrano relatywnie niewielką działkę (74 akry) w okolicy Queen Anne, częściowo będącą własnością miasta, zaniedbaną i pokrytą wieloma zdezelowanymi budynkami. Dotychczasowa 
lost space [3] stała się nowoczesnym miastem przyszłości na 6 miesięcy trwania wystawy, a po jej zakończeniu została przekształcona w Seattle Center - wciąż powiększającą się kolekcję muzeów, teatrów i przestrzeni wystawienniczych, rozmieszczonych na terenie aktywnie użytkowanego parku. Większość obiektów wystawowych została rozebrana. Pozostawiono najbardziej emblematyczne konstrukcje, pełniące dawne, jak i nowe funkcje - Space Needdle (dziś wieża obserwacyjna, restauracja), Colliseum (aktualnie hala widowiskowo-sportowa Key Arena) i United States Science Pavilion (obecnie kompleks kulturalny Pacific Science Center, Boeing IMAX) [6] [7] [8] [15] [43] [44]. Obiekty Century 21 Exposition stanowią niewyczerpane źródło inspiracji dla kolejnych realizowanych współcześnie w Seattle Center budowli. Pozostawioną po wystawie kolejkę monorail wykorzystał w swoim projekcie EMP Museum Frank O. Gehry (2000). Muzeum, stanowiące jeden z elementów rewitalizacji terenów post Expo'62, usytuowano na osi monorail - szybka kolejka, poruszająca się po torze wyniesionym na słupach, wjeżdża pomiędzy metaliczne fałdy „skóry” budynku i znika w jego wnętrzu, by potem pomknąć w kierunku dowtown [43]. Sama kolejka stanowi wciąż jedną z głównych atrakcji turystycznych miasta. Rozważane są nawet pomysły wydłużenia jej trasy.

Struktury urbanistyczne miasta i terenów wystawy 1962 r. są dobrze i synergicznie zintegrowane. Przestrzeń miasta, kształtowana w sposób nietypowy dla amerykańskich miast w oparciu o dostosowaną do topografii siatkę [43], zdaje się przepływać przez tereny postExpo nie tworząc wizualnych, ani fizycznych granic. Oferta funkcjonalna terenów Seattle Center w pełni odpowiada na zapotrzebowanie zarówno lokalne, jak i ośrodka kultury o krajowym i międzynarodowym zasięgu. Architektoniczne ikony Expo'62 - na czele ze Space Needdle, której dominująca pozycja w krajobrazie kulturowym miasta nie została do dziś zdystansowana nawet przez coraz wyżej pnące się wysokościowce - nadają miejscu oryginalną tożsamość, kształtując nowoczesny i optymistyczny wizerunek miasta, wpisując się w realizowaną w Seattle od początku XX wieku strategię tworzenia miejsc [43]. Stworzono tu miejsce z charakterem, z którym identyfikują się mieszkańcy, które napawa ich dumą i jest ważnym świadectwem ich historii. Wystawa stanowiła jeden z najsilniejszych impulsów w rozwoju i miała wielki wpływ na poprawę jego wizerunku [4].

SEWILLA 1929, 1992. W Sewilli odbyły się dwie wystawy światowe w 1929 r. i w 1992 r. Wystawa Ibero-Amerykańska 1929 r., odbywająca się równocześnie z wystawą światową w Barcelonie, jako wydarzenie prezentujące Hiszpanię jako potęgę kolonialną [8], została zorganizowana nad Gwadalkiwirem na terenach powstającego tam od $1893 \mathrm{r}$. parku Marii Luizy ${ }^{24}$ [46]. Od 1911 r. intensywnie prowadzono prace zmierzające do przeprojektowania parku, aby podnieść jego atrakcyjność dla celów planowanej w 1914 r. (bądź 1917) wystawy, kierowane przez Jean-Claude'a Nicolasa Forestier'a [8]. Ostatecznie wystawa doszła do skutku w 1929 r. Do tego czasu Forestier mógł na terenie przyszłego parku wystawowego w pełni rozwinąć swoją autorską koncepcję stylu, określanego jako „pseudomauretański” [30], silnie inspirowanego tradycją mauretańską i sztuką mudejar, mocno utożsamianymi z krajobrazem kulturowym Sewilli. Na rozległych terenach parkowych, poprzecinanych długimi, cienistymi alejami platanowymi, noszącymi imiona słynnych konkwistadorów, ukształtował szereg, inspirowanych ogrodami mauretańskimi wnętrz parkowych, wyposażonych w systemy urządzeń wodnych - fontann, sadzawek, kanałów, z rozległymi trawnikami i strzyżonymi żywopłotami, ramowanych pergolami, ozdobionych ceramicznymi amforami i rzeźbami, wykorzystującymi mudejarowe dekoracje z barwnych płytek azulejos [30] [46]. Styl neomudejarowy był obowiązującą estetyką, reprezentowaną

24 Teren o powierzchni 37,6 ha, stanowiący niegdyś część zespołu pałacowego San Telmo, został podarowany miastu przez infantkę Maríę Luisę 
w obiektach architektonicznych Wystawy Ibero-Amerykańskiej, co wpłynęło na wyrazisty i silnie identyfikowany $\mathrm{z}$ miastem wizerunek wystawy. Najpełniej przejawił się on w Pałacu Mudejarowym, w którym urządzono Muzeum Sztuk i Zwyczajów Ludowych. W architekturze budowli wykorzystano charakterystyczne elementy zdobnicze mudejaru, integrujące sztukę arabską i chrześcijańskiego średniowiecza, jak łuki podkowiaste, koronkowo wykończone ostrołuki, wysmukłe kolumny, stiukowe dekoracje plecionkowe i rytmiczne wzory z ceramicznych płytek. Wnętrza obiektu zdobią azulejos, tradycyjnie wyrabiane w Sewilli od XVI do XIX w. Główny architekt wystawy J. Espiau zaprojektował również elegancki neomudejarowy hotel Alfonso XIII, wykorzystujący podobne motywy dekoracyjne. Kulminacją założenia parkowego był Plac Hiszpanii (Plaza de España), stanowiący centralną i celebracyjną przestrzeń wystawową. Półkolisty plac otoczony piętrowymi galeriami z monumentalną sylwetą Pałacu Hiszpańskiego (Palacio Español) (proj. Aníbal González) stanowi eklektyczny konglomerat różnych stylów i motywów architektonicznych z hiszpańskiej przeszłości. Wątki neomauretańskie widoczne są w narożnych wieżach założenia, wzorowanych na słynnej sewilskiej Giraldzie, dawnym minarecie meczetu oraz $\mathrm{w}$ dekoracjach galerii z ławkami wykonanych $\mathrm{z}$ azulejos, ułożonych $\mathrm{w}$ sceny historyczne przedstawiające najważniejsze wydarzenia w dziejach 48 hiszpańskich prowincji [8] [30] [46]. Bardzo dobremu wpisaniu terenów Wystawy IberoAmerykańskiej 1929 r. w krajobraz Sewilli sprzyjała trafiona lokalizacja doskonale powiązana $\mathrm{z}$ miastem, a także wyrazista i jednolita stylistycznie koncepcja przestrzennoarchitektoniczna terenów i obiektów wystawowych, utrzymanych w stylach neomauretańskim i neomudejarowym, nawiązujących silnie do historii i tradycji gospodarza wystawy. Poza tym dla większości obiektów zaplanowano ich przyszłość - miały pozostać na terenach powystawowych na stałe pełniąc funkcje konsulatów, hoteli, muzeów i galerii sztuki, wzbogacając turystyczną i kulturalną ofertę miasta.

Sewilla po raz kolejny była gospodarzem wystawy w 1992 r. Expo, przyjmując motto The Era of Discoveries [6] [8], celebrowało 500-lecie odkrycia Ameryki przez Krzysztofa Kolumba $^{25}$ [8] [46] i kontynuowało wiele wątków wcześniejszej wystawy IberoAmerykańskiej 1929 r. Zorganizowana z wielkim rozmachem wystawa 1992 r., której przypisuje się znaczącą rolę we wskrzeszeniu medium Expo po latach kryzysu, zrealizowała również wiele politycznych celów, jak promocja profilu narodowego i rehabilitacja wizerunku Hiszpanii doby post-Franco. Realizując hasła „,przesuwania centrum Europy na południe" Hiszpania jednocześnie z Expo'92 weszła do wspólnej waluty europejskiej i była gospodarzem Igrzysk Olimpijskich w Barcelonie, osiągając wielki sukces w ramach szeroko zakrojonej narodowej strategii [6]. Na miejsce wystawy wybrano sztuczną wyspę Isla de la Cartuja na rzece Gwadalkiwir ze znajdującym się tam kompleksem dawnego klasztoru Kartuzów, niegdyś związanego z postacią Kolumba ${ }^{26}$ [46]. Podjęte przed wystawą prace infrastrukturalne, modernizacyjne i rewaloryzacyjne zmieniły całe miasto, znacząco podnosząc jakość przestrzeni i poziom życia mieszkańców. Wybudowano nowe drogi i autostrady, kilka nowych mostów, lotnisko (proj. Cruz/Ortiz), dworzec kolejowy (proj.

${ }^{25}$ Początkowo planowano, by także Chicago uczciło słynną wyprawę Kolumba równoczesną wystawą, lecz będące organizatorem wcześniejszych wystaw w 1893 i 1933 r., Chicago w ostatniej chwili wycofało się $\mathrm{z}$ tego pomysłu. [8] [46]

${ }^{26} \mathrm{Na}$ czas wystawy 1992 r. dawny klasztor Kartuzów Santa María de las Cuevas z XV wieku został odremontowany. Niegdyś Krzysztof Kolumb spotykał się tutaj z włoskim mnichem Gasparem de Gorricio, przygotowywał swoją drugą podróż przez Atlantyk i przechowywał swe najważniejsze dokumenty osobiste. Po śmierci jego zwłoki zostały tu pochowane na 27 lat w krypcie pod wzniesioną specjalnie w tym celu kaplicą. W 1841 r. klasztor przeszedł w posiadanie Charlesa Pickmana, londyńskiego biznesmena, który urządził tu wytwórnię ceramiki. [46] 
Rafael Moneo), uruchomiono szybką kolej do Madrytu. Historyczne centrum Sewilli zostało pieczołowicie odrestaurowane, wybudowano dwutysięczną jednostkę mieszkaniową i nowe obiekty użyteczności publicznej. Przygotowanie terenów wystawowych na wyspie stanowiło ogromne wyzwanie - suchy i jałowy teren wzdłuż rzeki leżący wiele lat odłogiem, został po ekstensywnych pracach w 1975 r. przeznaczony do zagospodarowania i rozwoju. Rzekę Gwadalkiwir skierowano w dawne koryto, przekopano kanał, przeprowadzono generalną kultywację i zazielenienie terenu, których skala i zakres były porównywane do oczyszczenia Forest Park na wystawę w Saint Louis w 1904 r. czy niwelacji Corona Dumps na Expo w Nowym Jorku w 1939 r. W rezultacie tych działań wyspa została przeobrażona w kwitnący ciąg parków i ogrodów z 350 tys. drzew i żywopłotami o łącznej długości ponad $40 \mathrm{~km}$. [6] [8] [46] Ogłoszono konkurs na projekt terenów wystawowych, którego jednym z głównych założeń było skuteczne powiązanie terenów Expo z miastem, odciętym od rzeki przez tereny kolejowe. Nie udało się jednak w pełni osiągnąć tego celu, ani w zwycięskim projekcie autorstwa Emilio Ambasza, proponującym penetrowanie terenów Expo przez metaforycznie rozlaną powodziowo rzekę z szeregiem małych basenów, ani w ostatecznej realizacji. Szerokość rzeki dawała odpowiednie przedpole dla ekspozycji spektakularnych budowli z promenady pod drugiej stronie. Tak więc wystawa oferowała atrakcyjną ekspozycję bierną z pawilonami widocznymi z miasta, ale była zamknięta na ekspozycję czynną, nie otwierając przed zwiedzającymi panoramicznych widoków historycznej Sewilli. Co więcej autostrada wzdłuż rzeki tworzyła niepożądaną barierę pomiędzy miastem a Expo [8]. Powiązania między wyspą Expo a miastem miały zapewniać nowe mosty, w tym La Barqueta-Mapfre i Alamillo, dzieła hiszpańskiego architekta Santiago Calatravy, które wraz z zaprojektowanymi przez niego pawilonem Kuwejtu, uznawanym za najciekawszy na Expo, stanowiły trampolinę w karierze architek$\operatorname{ta}^{27}$ [6] [8]. Białe i niezwykle ekspresyjne sylwety mostów Calatravy stanowią współcześnie wyróżniające się landmarki w panoramie Sewilli. Niezbyt kreatywny plan terenów wystawowych obejmował trzy strefy. Zwrócone tyłem do miasta regionalne pawilony Hiszpanii, formowały ciasne półkole wokół dużego basenu. Pawilony międzynarodowe usytuowano wzdłuż pięciu równoległych alei pod kątem prostym do kanału biegnącego przez cały teren. Budynki stałe, w tym Trian Tower (proj. F.J. Saénz de Oiza) i Pavilion of Discoveries (proj. J. Feduchi i E. Arroyo), zlokalizowano w trzeciej strefie. Niepodważalny był sukces Expo w zakresie prezentacji nowoczesnej architektury po postmodernistycznym zastoju [6]. Sam plan Expo nie zachwycał, ale budynki, utrzymane w optymistycznej, żywej kolorystyce, wypracowane detale, specjalnie projektowane i wykonane materiały, w tym głównie naturalny kamień i łatwo montowane blachy, odzwierciedlały wyrafinowanie współczesnej architektury [8]. Prócz obiektów Calatravy zapamiętane będą: pawilon Japonii projektu Tadao Ando ${ }^{28}$ [6] [7] [8], czy piękne i śmiałe konstrukcje autorstwa Jeana Nouvela czy Normana Fostera. Bardzo kreatywna była aranżacja krajobrazowa przestrzeni publicznych - pożądaną osłonę przed słońcem zapewniały ciągi drzew oraz zielone tunele i pergole. Od początku planowania Expo'92 tereny na Isla de la Cartuja były przewidywane do dalszego funkcjonowania po zamknięciu wystawy. Dziś obszar ten jest wykorzystywany na różne sposoby: główne pawilony, w tym Pabellón de España, wieża widokowa Torre Panorámica i inne budynki połączono, tworząc park tematyczny, oferujący pokazy multimedialne i stałe wystawy z dziedziny przyrody, nauki i kultury. Na Lago de España można

27 Pawilon Kuwejtu projektu Santiago Calatravy posiadał mechaniczny ruchomy dach, który w południe dla zapewnienia osłony przed ciepłem, zamykał swoje drewniane ,pazury”. [6] [8]

28 Pawilon japoński projektu Tadao Ando, największa drewniana konstrukcja na świecie, oferował niemal świętą przestrzeń. [6] [7] [8] 
obejrzeć egzotyczne wyspy oraz rekonstrukcję XVI-wiecznego portu sewilskiego. W nowoczesnym kinie Omnimax wyświetlane są filmy o Ziemi, dawnych poszukiwaczach przygód i lotach kosmicznych. Na zachód od terenu Expo znajduje się nowy park nauki i technologii z siedzibami międzynarodowych firm [46]. Bogatą ofertę funkcjonalną dopełnia strefa rozrywki z parkiem wodnym. Niewątpliwie Expo'92 odegrało witalną rolę w rozwoju Sewilli - planowanie urbanistyczne, nowa infrastruktura miejska, mosty, transport, drogi, telekomunikacja, budowle użyteczności publicznej, architektura krajobrazu i parki, ekstensywny program restauracji historycznej zabudowy - pozytywnie przekształciły miasto. W retrospekcji stanowiło landmark w kulturalnym wskrzeszeniu Hiszpanii w okresie post-Francowskim [6]. Niestety nie udało się synergicznie powiązać struktur wystawowych z miastem. Zrealizowany plan Expo poniósł fiasko w nawiązaniu interakcji pomiędzy starym i nowym. Lokalizacja Expo na wyspie pogłębiała izolację. Nie pomogły ani ekspresyjne formy mostów, łączników między terenami wystawy a miastem, ani bogata i atrakcyjna oferta funkcjonalna na terenach post-Expo [4].

MEDIOLAN 1906, 2015. Mediolan - międzynarodowa stolica targów i pokazów, gościł wystawy światowe dwukrotnie w 1906 i 2015 r. Wystawa 1906 r. została zorganizowana w samym sercu miasta na terenie parku Sempione ${ }^{29}$ założonego przy Zamku Sforzów w latach 1890-93 z dodatkowymi obiektami w rejonie Piazza d'Armi. Obie części na czas ekspozycji, zorganizowanej dla uświetnienia otwarcia Tunelu Simplońskiego, połączyła poprowadzona na estakadzie linia kolejki elektrycznej, wpisując się w główne motto wystawy „Transport”. Pod artystycznym nadzorem Sebastiana Locatiego na terenie parku i w okolicy wybudowano 225 pawilonów, z których do dzisiaj zachował się secesyjny budynek akwarium Acquario Civico [47]. Dziedzictwem wystawy 1906 r. jest największy mediolański park publiczny Parco Sempione - arcydzieło architektury krajobrazu i sztuki ogrodowej, z rozległą centralną łąką, ramowaną swobodnie prowadzonymi ścieżkami i laskami, tworzącymi kulisy głównej osi kompozycyjnej, perspektywistycznie wiążącej Castello i l'Arco della Pace, ulokowane na krańcach założenia. Znajdują się tutaj malownicze jezioro oraz liczne rzeźby ze słynnymi czterema „siostrami żeliwowymi” (aut. Tettamanti) na mostku Ponte delle Sirenette i pomniki, w tym cesarza Napoleona III. Park już po wystawie został doposażony w wiele znaczących obiektów architektonicznych i dzieł sztuki. Należy do nich Palazzo dell'Arte (proj. G. Muzio, wzniesione w 1933 r. na Triennale di Milano), obecnie siedziba Triennale Design Museum i miejsce czasowych wystaw artystycznych [47]. W ogrodach tej instytucji jest m.in. słynna fontanna Fontana dei Bagni Misteriosi (Fontana metafisica), autorstwa Giorgio de Chirico. Obok Palazzo de'l Arte wzniesiono wieżę widokową Torre Branca (proj. G. Ponti, 1933). Do ważniejszych obiektów, powiązanych z parkiem należą ponadto l'Arena - Stadio Civico, neoklasyczna budowla wzniesiona przez Luigi Canonica w 1806 r., czy Biblioteca del Parco (proj. I. Parisi i S. Longhi), zrealizowana na Triennale w 1954 r. [47] [48] [49] [50] Tak więc sam park i jego okolice sprzyjały od czasu wystawy 1906 r. lokalizacji obiektów o funkcjach wystawowych i targowych, co stało się swoistą specjalnością Mediolanu. W rejonie Piazza d'Armi, który był dodatkową lokalizacją wystawy 1906 r., od 1923 r. zaczęto urządzać Fiera di Milano (Targi Mediolańskie), aktywnie działające do 2007 r. Na tym 36 hektarowym terenie realizowane jest obecnie zakrojone na wielką skalę przedsięwzięcie urbani-

${ }^{29}$ Park Sempione został założony pod koniec XIX w. przez Emilio Alemagna, który przekształcił dawny ogród książęcy Viscontich o średniowiecznym rodowodzie 'il Barcho' i miejsce defilad przy Castello Sforzesco w park publiczny w stylu angielskim. Nazwa parku - rozciągającego się między Zamkiem Sforzów a Corso Sempione - celebrowała wielki przemarsz armii napoleońskiej przez Passo Sempione. Oś kompozycyjna parku wiąże Zamek i Łuk Triumfalny (Arco della Pace), stanowiący apoteozę zwycięstw Napoleona. Sempione to największy park publiczny w Mediolanie. [47] [48] [49] [50] 
styczne CityLife. Do 2023 r. ma tutaj powstać nowa dzielnica usługowo-mieszkaniowa. Ideą przewodnią projektu jest odwzorowanie cech pejzażu miasta i regionu. Za wizerunek tej wielkiej miejskiej inwestycji odpowiadają gwiazdy współczesnej architektury Zaha Hadid, Daniel Libeskind i Arata Isozaki. Według ich projektów mają powstać trzy wieże $I l$ Dritto (Prosta), lo Storto (Skręcona) i il Curvo (Zakrzywiona) - najwyższa już zrealizowana, druga w budowie, zespoły mieszkaniowe (dwa już zrealizowane) oraz Museum of Contemporary Art (MAC). Obiekty architektoniczne rozmieszczono wokół centralnego parku, tworzonego według projektu londyńskiego biura Gustafson Porter [47] [52] [53]. Na dawnych terenach post-Expo realizowany jest jeden z największych projektów urbanistycznych współczesności, który poprzedziła seria synergicznie powiązanych wydarzeń, zapoczątkowanych wystawą światową $1906 \mathrm{r}$.

O ile w przypadku wystawy 1906 r. zorganizowanej w parku Sempione, stanowiącym zielony salon miasta, dziś ulubione miejsce spacerów i wypoczynku mediolańczyków, ale też turystów udało się w pełni zrealizować założenia synergii, to ostatnie Expo 2015, które odbyło się na peryferyjnych obszarach w Rho pozostaje dalekie od realizacji takich założeń. By podkreślić ciągłość między obiema wystawami światowymi w Mediolanie, symboliczne wrota do Expo 2015 - w postaci symetrycznych, ażurowych, białych struktur (proj. Scandurra Studio) - ustawiono na Largo Beltrami, na osi Castello Sforzesco, za którym rozciąga się park Sempione. Na etapie planowania wystawy pojawiło się wiele pomysłów, które w zamierzeniu miały przyczynić się do urbanistycznej i kulturowej integracji terenów Expo z miastem. Cascina Merlata, czyli rozwój zachodnich obrzeży Mediolanu - stąd wybór gminy Rho, PIA Navigli Project, mający na celu poprawę kondycji i usprawnienie systemu kanałów, jednej z głównych atrakcji turystycznych, stanowiących częściową realizację wielkich mediolańskich projektów Leonarda da Vinci ${ }^{30}$, oraz Waterways Expo zamiar połączenia terenów Expo kanałem wodnym ze znajdującym się w historycznym centrum dokiem i starym portem La Darsena. Kanał miał być osią zielonych terenów rekreacyjnych z 20-kilometrową ścieżką rowerową. Jej realizacja nie doszła do skutku ze względu na sprzeciwy ekologów. Podobnie fiaskiem zakończyły się również pozostałe wyżej wymienione plany [54]. Waterways Expo zamknęło się jedynie rewaloryzacją doku i dawnego portu oraz oblaniem terenów Expo wokół kanałem wodnym. Inspiracje i odwołania do pomysłów Leonarda podsumowano serią rozproszonych w całym mieście wystaw, prezentujących dokonania artysty oraz akcentem rzeźbiarskim Leonardo Icon (proj. Daniel Libeskind) ${ }^{31}$ ustawionym przed Pinakoteką Ambrosiana. Szansą na urbanistyczną rehabilitację Expo była - również niedoszła do skutku - realizacja generalnego planu wystawy opracowana przez biuro Herzog de Meuron $^{32}$ we współpracy z Stefano Boerim, Ricky Burdettem i Williamem McDonoughem. Koncepcja zakładała zerwanie z dotychczasową rywalizacją architektoniczną między pawilonami, którą uznano za XIXwieczny przeżytek. Pawilony miały przyjąć ujednoliconą formę, a całość terenów miała być podporządkowana rygorowi geometrycznemu $\mathrm{w}$ oparciu o dwie przecinające się pod kątem prostym osie cardo i decumanus - w nawiązaniu do planów antycznych obozów legionów rzymskich, które stały się kanwą urbanistyczną wielu miast europejskich [54]. Ostatecznie pawilony

${ }^{30}$ W latach 1508-1510 Leonardo da Vinci na zlecenie księcia Sforza stworzył plan rozbudowy Mediolanu, będący propozycją deglomeracji miasta poprzez budowę 10 miast satelitarnych, każde po 300 tys. mieszkańców. Jest on również autorem szeregu planów, zakładających budowę kanałów i innych usprawnień systemów wodnych, jak m.in. projekt uspławnienia rzeki Arno i połączenia łukowatym kanałem Florencji z Pistoją.

${ }^{31} \mathrm{Na}$ kolistym brązowym postumencie rzeźby znajdują się motywy z Kodeksu Atlantyckiego f. $199 \mathrm{v}$ Mapa Mediolanu, z planem Castello Porta Giovia, autorstwa Leonarda da Vinci. [55]

32 Jacques Herzog i Pierre de Meuron 
otrzymały indywidualne, konkurujące ze sobą formy, pogłębiające wrażenie przestrzennej kakofonii. Udało się zrealizować osie: dłuższą decumanus z ulokowanymi wzdłuż niej pawilonami narodowymi oraz krótszą cardo, służącą prezentacji Włoch i akcentowaną na zakończeniu strefą celebracyjną Lake Arena z umieszczoną w centrum owalnego basenu rzeźbiarską instalacją Drzewo Życia, symbolem Expo 2015. Temat wystawy „Wyżywić planetę. Energia dla życia” mógł sugerować podkreślenie w kompozycji całości terenów zieleni. Rzeczywiście pojawiło się wiele pomysłowo aranżowanych przestrzeni ogrodowych - ogrodów na dachach, ogrodów wertykalnych, zielonych ścian, ogrodów jadalnych, itp., realizujących raczej ideę „ogrodu w pigułce” czy „ogrodu kieszonkowego”. Szumnie nazwane „ogrodem bioróżnorodności” wąskie pasmo ze ścieżką prowadzącą między nasadzeniami z śródziemnomorskiej roślinności rodzimej na tyłach zabudowy, Wzgórze Śródziemnomorskie, usypany z ziemi z odzysku regularnie ukształtowany pagórek, czy Park Dzieci, skupiony na interaktywnych urządzeniach edukacyjnych - stanowiły rozwiązania fragmentaryczne, nie powiązane ze sobą, szczątkowe, które tylko wzmacniały wrażenie dominacji tworzywa architektonicznego na terenach Expo [47] [51] [54] [56]. Kompozycja architektoniczna Expo była daleka od jednolitości i spoistości, brakowało wyrazistych dominant, a koncepcja użytkowania post-Expo zakładała rozebranie większości obiektów, bez pozostawiania fizycznych śladów wystawy. Pod względem urbanistycznym i kompozycyjnym teren Expo 2015 w Rho wydaje się być powiązany wyłącznie z położonym obok centrum targowym Fieramilano (proj. Massimiliano Fuksas) [57], co widoczne jest np. w układzie głównych osi kompozycyjnych, czy zbliżonych proporcjach i wielkościach. Natomiast obiekty Fieramilano mają zdecydowanie atrakcyjniejszą wizualnie oprawę z ekspresyjnymi, giętymi, przeszklonymi strukturami stanowią o wiele bardziej wyrazisty landmark przestrzenny w okolicy. Oferując świetnie zorganizowaną przestrzeń targowoekspozycyjną są prawdopodobnie silniejszym konkurentem w zestawieniu z terenami postExpo. Wydaje się więc, aczkolwiek może są to wnioski przedwczesne i trzeba by minęło przynajmniej kilka lat od Expo, że nie udało się tutaj osiągnąć efektu synergii, tak świetnie działającego w przypadku wcześniej opisanych wystaw. Powodów można doszukiwać się w zbyt odległej od miasta lokalizacji terenów wystawowych, dodatkowo jeszcze okolonych kanałami wodnymi, co pogłębia wrażenie izolacji, słabości powiązań z historycznym centrum czy braku wyrazistych i emblematycznych dominant architektonicznych, które mogłyby poszerzyć listę turystycznych atrakcji miasta [4].

SZANGHAJ 2010. Tereny Expo 2010 r. w Szanghaju ulokowano na przeciwległych brzegach rzeki Huangpu, przy czym w 2/3 w prężnie rozwijającej się od lat 90 . XX w. nowoczesnej dzielnicy Pudong, resztę - w poprzemysłowej dzielnicy Puxi. Mimo znacznych odległości od centrum miasta, lokalizacja poprzez oś rzeki zapewniała powiązania widokowe - dostępne z głównego placu Expo Celebration Square - z atrakcyjną panoramą wysokościowców w Pudong i efektowną promenadą Bund zmodernizowaną na Expo, współczesnymi wizytówkami Szanghaju. Teren Expo był budowany od podstaw, stając się przyczynkiem do wielkiej przemiany miasta. Wpisując się w miejską strategię restrukturyzacji przemysłu, wykorzystano rozległe obszary zajęte dotychczas przez stocznie i huty, oczyszczono 2,6 km² zdegradowanych terenów wzdłuż nabrzeży Huangpu, przekształcając je w parkowe przestrzenie publiczne, przywracając je miastu i rozwiązując wiele problemów środowiskowych. Expo 2010 poprzedziły wielkie miejskie inwestycje, jak rozbudowa sieci metra i kolei, nowe lotnisko, budowa mostów, w tym Lupu i Nanpu, między którymi rozciągały się tereny Expo, hoteli, zaplecza usługowego i miasteczka wystawowego. Największym beneficjentem Expo’2010 - prócz branży wystawienniczej - stał się przemysł turystyczny, profitując nie tylko w Szanghaju, ale też w szerszym rejonie Delty Rzeki Jangcy [58] [59] [60] [61] [70]. Największe Expo w dotychczasowej historii wyposażono 
w emblematyczne obiekty o oryginalnej formie i skali, przeznaczone do pozostawienia po zakończeniu wystawy. Zgrupowano je w rejonie głównej osi kompozycyjnej i funkcjonalnej Expo Boulevard, zakończonej na nabrzeżu placem Expo Celebration Square - znakomitą płaszczyzną widokową, skąd poprzez rzekę rozciągała się panorama miasta. Rolę głównej bramy i charakterystycznego landmarku Expo pełniła membranowa struktura Expo Axis, metaliczny spodek Expo Performance Center, stanowił dominantę placu nad rzeką i futurystycznie prezentował się niczym „dryfujące miasto" z mostem Lupu w tle, przeciwległą ścianę placu kształtował przeszklony prostopadłościan Expo Center. Główną oś Expo ramowały Theme Pavilions - zespół składający się z trzech pawilonów Urban Planet, City Being i Urbanian, pełniących funkcje usługowe i gastronomiczne, nawiązujących architektonicznie do zabudowy tradycyjnej szanghajskiej uliczki z mansardami. Kulminacją założenia wielkiej osi był Pawilon Chin, wyróżniający się na tle innych obiektów skalą, oryginalną schodkową formą i czerwoną kolorystyką. Nazwany „Koroną Wschodu”, egzemplifikował charakterystyczne elementy tradycyjnej chińskiej architektury, jak wsporniki Dougong, czy kaligraficzne znaki. Na dachu urządzono ogród według prawideł chińskiej sztuki ogrodowej [6] [61] [62] [63]. Pozostałe sektory zajmowały pawilony narodowe i instytucjonalne, obiekty czasowe, stanowiące efemeryczne dziedzictwo Expo. Doceniając pomysłowość oraz innowacyjność rozwiązań architektonicznych i technologicznych pawilonów, trudno oprzeć się wrażeniu, że Expo, którego motywem przewodnim było „Lepsze Miasto. Lepsze Życie", rozczarowywało na poziomie urbanistycznym oferując konwencjonalne i pozbawione inwencji rozplanowanie miasteczka Expo. Nie w pełni wykorzystano walory krajobrazowe lokalizacji i możliwości powiązania terenów wystawowych z rzeką. Połączenia między częściami po obu stronach Huangpu odbywały się metrem poniżej poziomu terenu, bądź niezbyt wydajną przeprawą promową. Brak urbanistycznej synergii i ciągłości sprawiał, że obie części Expo nie działały jako całość, pogłębiając wrażenie separacji. Jeden z kluczowych konceptów urbanistycznych - wyniesiona powyżej poziomu terenu kładka piesza, przecinająca tereny ekspozycyjne - nie należała do szczególnie nowatorskich, dodatkowo komplikowała układ komunikacyjny i utrudniała zwiedzanie.

Synergia widoczna była o wiele bardziej w zakresie koncepcji terenów zieleni, zaspokajających nie tylko potrzeby akomodacji i rekreacji zwiedzających, ale również rozwiązujących wiele kwestii środowiskowych w skali całego miasta. By sprostać tematowi „Lepsze Miasto. Lepsze Życie” wiele wysiłku włożono w poprawę jakości środowiska, dokładając również ten aspekt do pozytywnej przemiany Szanghaju. O 40\% wzrosło pokrycie miasta zielenią $^{33}$. Położono nacisk na zieloną infrastrukturę, pasy zieleni typu greenbelt, parki, zwiększenie możliwości spacerowania i jazdy na rowerze, przestrzenie wielofunkcyjne (łączące sektory mieszkalnictwa, komercji, usług i sztuki), osiedla mieszkaniowe o wysokiej intensywności, ograniczenie ruchu samochodowego w centrum miasta i rozwój miejskiego transportu publicznego [64]. Zieleń Szanghaju powiązano w system, obejmujący lasy i obszary otwartego krajobrazu, nabrzeża rzek, pasy zieleni, zieleń przyuliczną i publiczną. Specjalna strefa Huangpu River Central Area, obejmująca również tereny Expo, znalazła się w zasięgu zakrojonego na wielką skalę projektu zazieleniania i porządkowania nabrzeży [60]. Dla realizacji podtematu „Zielone Expo i Eco-Expo” opracowano plan przestrzeni zielonej zintegrowany z generalnym master planem, zakładający rewitalizację obszaru przy uwzględnieniu problemów środowiskowych nabrzeża Huangpu, w tym

33 Comprehensive Plan of Shanghai (1999-2020) przewidywał ogromny wzrost powierzchni terenów zielonych. Całkowita powierzchnia parków, ogrodów i terenów zieleni w 2005 r. wynosiła 28,865 hektarów (1,738 ha w 1980 r.), a pokrycie zielenią stanowiło 37\% (8,2\% w 1980 r.). Do 2010 r. przewidywano dalszy wzrost. [64] 
zanieczyszczenia terenu, powietrza i wody oraz ochrony przeciwpowodziowej. Celem było stworzenie podstaw zrównoważonego systemu zieleni, włączającego się efektywnie w tkankę miejską po Expo. W perspektywie długoterminowej ma to zaowocować zwiększeniem bilansu zieleni, poprawą stanu środowiska, a tym samym jakości życia w mieście. System zieleni Expo ukształtowano w postaci rozciągającej się od nabrzeży Huangpu do terenów zurbanizowanych ekologicznej sieci, którą tworzyły:

- „zielony rdzeń” - tereny parkowe integrujące zieleń nabrzeża z terenami Expo. Rdzeń tworzy Expo (Shibo) Park - główna scena aktywności Expo, funkcjonujący nadal po zakończeniu wystawy ${ }^{34}$. Projekt parku (arch. krajobrazu Zhu Shengxuan ${ }^{35}$ ) uwzględniał zarówno potrzeby wystawy (komunikacja, rekreacja, bezpieczeństwo i ewakuacja, edukacja ekologiczna, cele reprezentacyjne), jak i funkcje największego, zrównoważonego ekologicznie i wcielającego idee miejskiej ekologii, parku w centrum Szanghaju. Koncepcja parku opiera się na wiodących motywach 'bund' ${ }^{36}[70]$, kojarzonym również z historyczną dzielnicą Szanghaju Bund, 'wachlarz' oraz na wschodniej filozofii natury 'Shanshui'37 [65], silnie eksponujących genius loci. Wachlarzowe wpisanie parku w topografię nabrzeża rzeki, łączące nasypy ziemne w trójwymiarowy system z transportem na wyższych poziomach i tarasowymi ogrodami, zamiast wysokich wałów i murów przeciwpowodziowych, pozwoliły na skuteczne powiązanie miasta z rzeką. Stworzono zbalansowane środowisko roślinne, wykorzystując naturalne ekosystemy, dostosowując nasadzenia do nadwodnego siedliska i symulując naturalny nadrzeczny krajobraz. Uwzględniono biologiczne oczyszczanie i recykling wody, alternatywne ekotechnologie w zakresie poprawy jakości powietrza i mikroklimatu, infrastruktury technicznej, zwłaszcza w rozwiązaniach ochrony przeciwpowodziowej [59] [61] [63] [65] [66].

- „zielona oś” - Expo Boulevard, główna oś terenów wystawowych;

- „zielone pasy” - parki nadrzeczne (Houtan, Bailianjing) wzdłuż Huangpu i Bailian, prezentujące eko- i bioróżnorodność, siedliska różnych gatunków rodzimych i importowanych [63]. Houtan Park - zaprojektowany zgodnie z ideami Turenscape - to innowacyjna demonstracja miejskiej ekologii Expo'2010. Stanowi krajobrazową i ekologiczną projekcję idei „Zielonego Expo”, prezentację eko-technologii i eko-rozwiązań problemów środowiskowych i przeciwpowodziowych. Celem było przywrócenie do życia terenów poprzemysłowych $\mathrm{i}$ ich zasadnicza transformacja w stały publiczny park nadrzeczny. Teren przekształcono w żyjący system, oferujący kompleksowe usługi ekologiczne: miejskie rolnictwo, zabezpieczenia przeciwpowodziowe, uzdatnianie wody i tworzenie siedlisk, połączone z aspektami edukacyjnymi i nowoczesną estetyką architektoniczną. Osią parku są samooczyszczające się mokradła, ostoja i naturalne siedlisko dla wielu gatunków roślin, organizmów żywych i ptaków. Woda z rzeki jest natleniana i uzdatniana poprzez serię kaskad i tarasów, inspirowanych chińskimi tradycyjnymi polami ryżowymi. Zastąpiły one wysokie mury przeciwpowodziowe, do tej pory skutecznie odcinające dostęp do rzeki. Z wąskiego, zdegradowanego wąskiego skrawka terenu pomiędzy brudną rzeką, a hałaśliwą drogą ekspresową stworzono bezpieczną, przyjazną ekologicznie i estetycznie satysfakcjonującą przestrzeń publiczną. Doniosła jest też rola Houtan Park w przyciąganiu globalnej uwagi na współczesne trendy w architekturze krajobrazu oraz pokazywanie potencjału energii krajobrazowej, przynoszącej korzyści społeczne, kulturalne i ekologiczne [61] [67] [68] [69];

\footnotetext{
34 Expo Park jest wykorzystywany jako uzupełniająca przestrzeń publiczna post-Expo, organizowane są tam wydarzenia kulturalne, festiwale itp.

35 NITA Group of Netherlands

36 Słowo bund oznacza nabrzeże, bulwar, wał.

37 'Shansui' oznacza 'Górę i Wodę'. [65]
} 
- zielone przestrzenie dekoracyjne - tereny zieleni pomiędzy poszczególnymi kwartałami i obiektami Expo pełniące funkcje estetyzujące i rekreacyjne oraz pasy buforowe między Expo a miastem wpływające na oczyszczanie powietrza, zmniejszanie poziomu zanieczyszczenia hałasem, itp.;

- „zielone kliny” - prostopadłe do rzeki pasma, integrujące zieleń Expo z tkanką miejską;

- „zielone łańcuchy” - zieleń towarzysząca komunikacji [59].

Po Expo na zrewitalizowanym nabrzeżu Huangpu pozostały założenia Expo Park, Houtan i Bailianjing, będące równocześnie elementami szerszej strategii regeneracji środowiskowej nabrzeży Huangpu Riverside Regeneration Program. Połączone w linearny system stanowią ogromny rezerwuar terenów zielonych w centrum miasta oraz istotne ogniwo w procesie naprawy środowiska przyrodniczego, świadcząc usługi ekosystemowe, czy będąc miejscem edukacji ekologicznej i badań. Niepodważalnym i dalekosiężnym dziedzictwem Expo 2010 jest synergetyczna sieć powiązań przyrodniczych, łącząca tereny post-Expo z miastem. Plan użytkowania post-Expo zakłada dalsze funkcjonowanie obszaru przy wykorzystaniu pozostałej infrastruktury architektonicznej dla celów reprezentacyjnych, muzealnych, wystawienniczych, kongresowych, targowych, itp. Zasadnicza część terenów w Pudong, zorganizowana wokół Expo Boulevard ma pełnić funkcje centrum kongresowo-wystawowo-biznesowego. Tereny położone bardziej na północ to Strefa Obiektów Rządowych. Obszary, na których w czasie Expo znajdowały się pawilony narodowe to Strefa Rozwoju Expo Houtan, wykorzystująca lokalizację Houtan Park na nabrzeżu jako stymulator rozwoju mieszkalnictwa. Tereny położone na drugim brzegu rzeki w Puxi to Strefa Kultury i Wystaw oraz tereny, gdzie mają być prezentowane „Najlepsze Praktyki Urbanistyczne" ${ }^{38}$ [61]. W 2014 r. powystawowe użytkowanie głównej osi Expo Boulevard nie wykorzystywało w pełni potencjału miejsca. Ograniczało się do funkcji muzealnych w dawnym Pawilonie Chin, stanowiącym najbardziej wyrazistą krajobrazową ikonę Expo, organizacji wydarzeń artystycznych i targowych w Expo Center, czy Performing Arts Center (Arena Mercedesa). Wokół toczyły się prace budowlane, których efektem będzie powstanie na terenach post-Expo tętniących „Lepszym Życiem” wielofunkcyjnych dzielnic „Lepszego Miasta”, wcielających wysokiej jakości praktyki urbanistyczne i wykorzystujących zastrzyk energii, jakie dała organizacja w tym miejscu wystawy światowej. W Puxi od 2012 r. trwa budowa World Expo Museum - pierwszego w świecie muzeum prezentującego historię i osiągnięcia wystaw światowych, którego otwarcie ma nastąpić w 2016 r. [61] [71] [72] [73] Expo było szansą optymalizacji przestrzennej tkanki metropolii, wykorzystania zdobyczy najnowszych trendów urbanistycznych XXI wieku w duchu zrównoważonego rozwoju i ,zielonej ekologii”, co zapowiadały główne hasła wystawy. Udało się w dużej części te wielkie zamierzenia zrealizować, głównie dzięki programowi rewitalizacji nabrzeża Huangpu, odpowiadającemu na trudne problemy środowiskowe zdegradowanych przez przemysł terenów. Parki post-Expo cały czas pracują na rzecz poprawy jakości życia mieszkańców. To struktury post-Expo, powiązane synergiczną siecią z miastem, nakreślają perspektywy dalszego rozwoju. Szanghaj - najbardziej energetyczne i przyszłościowo myślące miasto Chin - staje się modelowym przykładem ,zielonego" projektowania urbanistycznego, chlubiąc się coraz czystszym powietrzem, nowoczesnymi parkami publicznymi i zielonymi nabrzeżami, zrównoważoną infrastrukturą transportową i wielkoskalowymi rezerwuarami otwartych przestrzeni zielonych [4] [6] [7] [58] [61] [59] [64] [70] [73] [74].

38 Tereny Expo'2010. Schemat funkcjonalny użytkowania post-Expo. Muzeum Planowania Miejskiego w Szanghaju, 2014. 


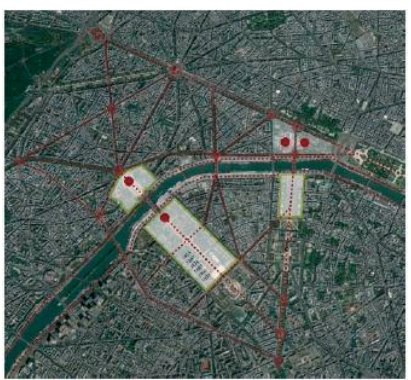

PARYŻ 185518671878188919001937

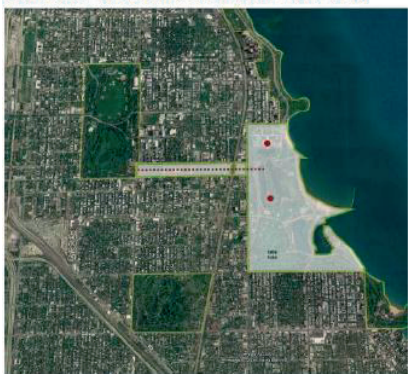

CHICAGO 18931933

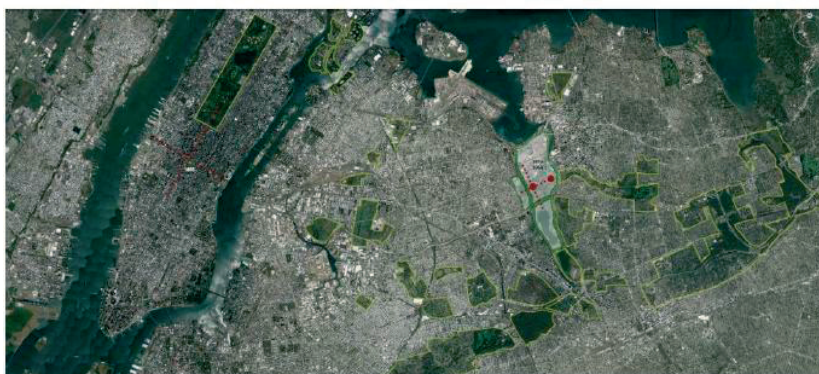

NOWY JORK 185319391964

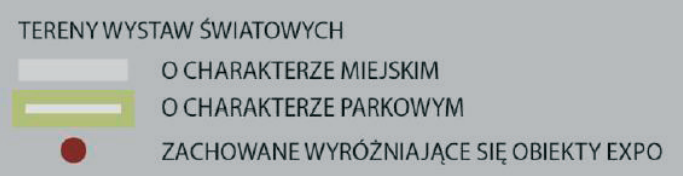

TERENYWYSTAW SWIATOWYCH

O CHARAKTERZE MIEJSKIM

ZACHOWANE WYRÓŻNIAJĄCE SIĘ OBIEKTY EXPO

BARCELONA 18881929

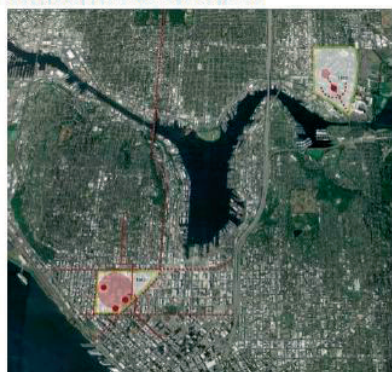

SEATTLE 19091962
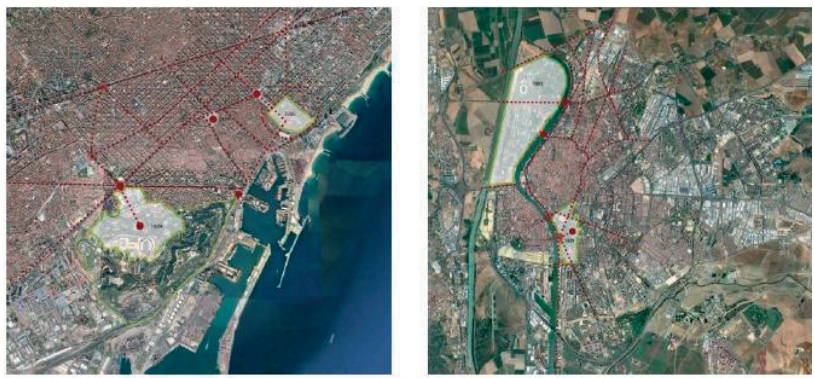

SEWILLA 19291992

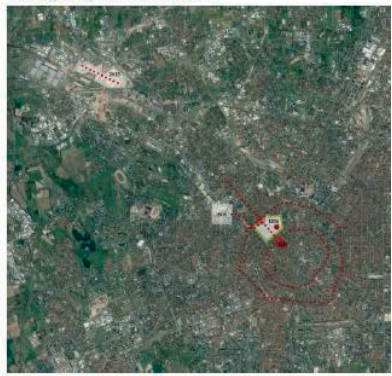

MEDIOLAN 19062015

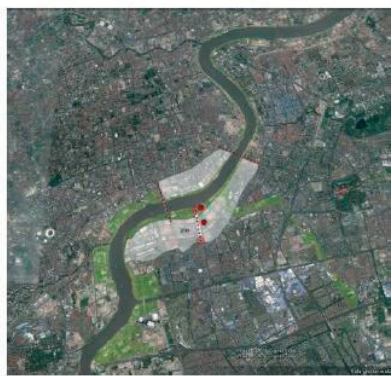

SZANGHAJ 2010

Rys. 1. Schematy synergicznych powiązań wybranych terenów wystaw światowych i struktur miastgospodarzy. Opr. I. Sykta

\section{Wnioski}

Jak wystawę światową, wydarzenie o charakterze czasowym można wykorzystać ponadczasowo i sprawić by Expo przynoszące ogromne korzyści dla miasta-gospodarza w czasie swego trwania benefitowało nadal po zakończeniu wystawy? Synergia struktur przestrzennych post-Expo i tkanki urbanistycznej miasta-gospodarza wydaje się dawać odpowiedź na wyżej postawione pytanie, co potwierdzają analizy wybranych przykładów wystaw światowych, zarówno tych, którym udało się z sukcesem zintegrować tereny i obiekty post-Expo z miastem, jak i tych, które nie w pełni wykorzystały ten potencjał. Owa integrująca synergiczna sieć opiera się na: 
- powiązaniach urbanistycznych, kształtowanych przez jednoczące struktury przestrzeni publicznych - osie kompozycyjne, aleje, promenady, pasaże, place, itd. oraz różnego rodzaju i skali wyróżniki przestrzenne - dominanty architektoniczne, wieże, bramy, pomniki, elementy małej architektury i informacji wizualnej, itp., stanowiące trwałe dziedzictwo wystaw;

- powiązaniach przyrodniczych, wpisujących tereny post-Expo - nowe parki i ogrody, zrewitalizowane nabrzeża i tereny poprzemysłowe, dawne lost spaces - w systemy terenów zieleni miejskiej i struktury zielonej infrastruktury.

Synergiczne sieci powiązań urbanistycznych i przyrodniczych, wpisując się w strukturę krajobrazową, efektywnie i efektownie wpisują obiekty post-Expo w makrownętrze miasta. Obraz i panorama miasta zyskują nowe dominanty, subdominanty, akcenty, landmarki, eye-catchers, itp. identyfikowane $\mathrm{z}$ wystawami światowymi i budujące specyficzną tożsamość miasta-gospodarza. Kształtują genius loci i stają się istotnymi elementami krajobrazu mentalnego, gdzie - stosując określenia K. Lyncha [75] - tereny post-Expo można identyfikować jako „węzły” lub „rejony”, a wyróżniające się obiekty post-Expo jako „punkty orientacyjne”. Często wyróżniające się obiekty post-Expo, przyciągając aurą artystycznej prowokacji i oryginalnością formy, generują nowe atrakcje turystyczne [12] [13] [14]. Mogą się one stać osnową sieci tematycznych szlaków turystycznych, a miasto może czerpać korzyści ze sprzedaży ich wizerunku.

Aby tereny i obiekty post-Expo synergicznie mogły wykorzystywać swój potencjał po zakończeniu wystawy powinna zaistnieć triada trzech sprzężonych ze sobą czynników, które należy uwzględnić na etapie planowania Expo oraz w planie użytkowania i utylizacji post-Expo. Czynniki te to: lokalizacja, kompozycja urbanistyczno-krajobrazowa i koncepcja funkcjonalna Expo. Lokalizacja powinna być zintegrowana $\mathrm{z}$ istniejącą tkanką urbanistyczną miasta, posiadać dobre powiązania komunikacyjne (np. Paryż, Barcelona, Mediolan 1906, Sewilla 1929, Seattle), bądź - przy mniej centralnym położeniu - wpisywać się w system terenów otwartych czy zieleni miasta (Chicago, Nowy Jork 1939, 1964, Szanghaj). Kompozycja urbanistyczno-krajobrazowa terenów Expo w wyrazisty i oryginalny sposób powinna eksponować struktury wystawowe w przestrzeni miasta. Najskuteczniejsze w oddziaływaniu są formy silne, o dużym polu działania formalnego [1]. Im kompozycja terenów post-Expo bardziej spoista (symetria, osiowość, silna artykulacja dominant, akcentowanie, itp.), formy obiektów post-Expo - wyraziste, emblematyczne i determinujące wizerunek otoczenia, a ich stylistyka architektoniczna jednoznaczna i tożsama z kompozycją całości terenów wystawowych, ale także wykorzystująca elementy genius loci (historia, tradycja miejsca), tym większa ich identyfikacja, wyróżnialność w strukturze przestrzennej miasta. Taka szczególna koincydencja tych elementów miała miejsce w przypadku wystaw paryskich, barcelońskich, ale także zaistniała w Chicago w 1893 r., Sewilli w 1929 r., Seattle czy Szanghaju. Wydarzenia te pozostawiły bardzo wyraziste architektoniczne i urbanistyczne ślady w mieście, emblematyczne obiekty, które w wielu wypadkach stanowią wizytówki czy logo miast-gospodarzy. Ważne jest również by plan terenów Expo stanowił kompozycję otwartą, o przepuszczalnych granicach, dających możliwość swobodnego przenikania struktur przestrzennych terenów post-Expo i miasta. Zbyt wyraziste granice (Mediolan 2015), a zwłaszcza lokalizacja na wyspie (Sewilla 1992), nie sprzyjają synergii z miastem. Koncepcja funkcjonalna Expo powinna zakładać pozostawienie części, zwłaszcza tych najbardziej symbolicznych struktur, do dalszego działania po zakończeniu wystawy. Plan użytkowania post-Expo nie powinien ,zamrażać” terenów wystawowych, a raczej zakładać wykorzystanie istniejącej infrastruktury i pozostawionych obiektów dla nowych funkcji. Celowe wydaje się również dopełnienie terenów post-Expo o nowe 
obiekty, pełniące funkcje atrakcyjne dla mieszkańców i turystów, jak: kultura, nauka, technika, sport, rekreacja i wypoczynek, turystyka.

Wystawy światowe - organizowane od połowy XIX wieku do dzisiaj - przyniosły wiele wszechstronnych zarówno lokalnych, jak i ponadlokalnych profitów. Były jednak i takie, w których zabrakło synergii w skutecznym powiązaniu terenów post-Expo ze strukturami przestrzennymi miast-gospodarzy. Ale nawet w tych przypadkach można mówić o nadzwyczajnym fenomenie wystaw światowych, które pozytywnie zmieniły wizerunek i przestrzeń wielu miast, benefitując $w$ wielu strefach i podnosząc jakość życia. Na organizacji Expo zyskiwały, często wydobywane $\mathrm{z}$ urbanistycznego niebytu tereny lokalizacji wystaw, jak i miasta-gospodarze jako całość. Zyskiwały tym bardziej im większa była synergia pomiędzy tymi strukturami, potwierdzając wynik równania syntezy energii „2+2=5”. Wynik ten gwarantowało synergiczne sprzężenie zwrotne EXPO $\leftrightarrow$ MIASTO.

\section{Literatura:}

1. Żórawski J., O budowie formy architektonicznej, Arkady, Warszawa 1973.

2. Böhm A., O budowie i synergii wnętrz urbanistycznych, Politechnika Krakowska, Kraków 1981.

3. Trancik R., Finding Lost Space: Theories of Urban Design, J. Wiley, New York 1986.

4. Sykta I., The impact of Worlds' Exhibitions on landscape and development of cities. Urban, architectural park and symbolic legacy of expos, [w:] CRACOW LANDSCAPE MONOGRAPHS VOL. 3. Landscape as impulsion for culture: research, perception \& protection. Problems of Protection \& Sharing. Kraków 2016, Institute of Archeology. Jagiellonian University. Institute of Landscape Architecture. Cracow University of Technology, s. 71-87.

5. Sykta I., Znaczenie wyróżniajacych się, kontrowersyjnych obiektów architektury wspótczesnej dla kształtowania i percepcji krajobrazu miejskiego, Praca doktorska, prom. A. Böhm, Politechnika Krakowska, Kraków 2008.

6. Greenhalgh P., Fair World. A History of World's Fairs and Expositions from London to Shanghai 1851-2010, Papadakis, Winterbourne, Berkshire, Great Britain 2011.

7. Jackson A., Expo. International Expositions 1851-2010, V\&A Publishing, London 2008.

8. $\quad$ Mattie E., World's Fairs, Princeton Architectural Press, New York USA 1998.

9. Pommereau C. (ed.), Paris 1900. La Ville Spectacle, Petit Palais, BeauxArts / TTM Éditions, Paris 2014.

10. de Jong C., Mattic E., Architectural Competitions 1792 - Today, Taschen, Kolonia 1994.

11. Sosnowska J.M. (red.), Wystawa paryska 1937. Materiały z sesji naukowej Instytutu Sztuki PAN Warszawa, 22-23.10.2007, Instytut Sztuki Polskiej Akademii Nauk, Warszawa 2009.

12. Sykta I., Kontrowersyjne obiekty architektury współczesnej - ryzykowne eksperymenty w historycznym centrum miasta, [w:] Czasopismo Techniczne - Serce miasta, Seria Architektura, z. 4-A/2008, Zeszyt 9 (ROK 105), wyd. Politechniki Krakowskiej, Kraków 2008, s. 161-168.

13. Sykta I., 'Cityscape scrapers' - kontrowersyjne obiekty architektury współczesnej w krajobrazie miejskim jako element ogniskujący rozwój rekreacji i turystyki, [w:] Nauka Przyroda Technologie, tom 3, Zeszyt 1, wyd. Uniwersytetu Przyrodniczego w Poznaniu, Poznań 2009, ss. 10, http://www.up-poznan.net

14. Sykta I., Ekonomiczne aspekty turystyki kulturowej - szlakiem kontrowersyjnych obiektów architektury wspótczesnej w krajobrazie miast historycznych, [w:] M.K. Leniartek, K. Widawski (red.), Nowa Ekonomia Turystyki Kulturowej, Seria: Monografie - Prace zbiorowe Wyższej Szkoły Zarządzania „Edukacja” we Wrocławiu, Wydawnictwo Wyższej Szkoły Zarządzania „Edukacja” Wrocław 2012, s. 175-195.

15. Sykta I., Ewolucja idei postępu i wizji miast przyszłości zapisana w krajobrazach, obiektach i pokazach wystaw światowych - od Londynu 1851 do Nowego Jorku 1939. Evolution of the idea of progress and visions of future cities encoded in the landscapes, architectural structures and shows of world exhibitions - from London 1851 to New York 1939 [w:] Przestrzeń i Forma'21/2014, s. 353-376; http://www.pif.zut.edu.pl/pif-21_pdf/C-08_PiF21_Syktai.pdf

16. Bolotin N. \& Laing C., The World's Columbian Exposition. The Chicago World's Fair of 1893, 
University of Illinois Press Urbana and Chicago, Champaign Illinois USA 2002.

17. Wille L., "A City Circled by Parks". Forever Open, Clear, and Free; the Historic Struggle for Chicago's Lakefront. 2nd ed. Chicago: U of Chicago, 1991. 54. Print.

https://en.wikipedia.org/wiki/Jackson_Park_(Chicago) [dostęp 10.02.2016].

18. Rydel R.W., Burd Schiavo L. (eds.), Designing Tomorrow. America's World's Fairs of the 30s, Yale University, New Haven and London 2010.

19. Jackson Park (Chicago), https://en.wikipedia.org/wiki/Jackson_Park_(Chicago) [dostęp 10.02.2016].

20. Chicago Park District. Jackson Park, http://www.chicagoparkdistrict.com/parks/jackson-park/ [dostęp 10.02.2016].

21. Midway Plaisance, https://en.wikipedia.org/wiki/Midway_Plaisance [dostęp 10.02.2016].

22. Chicago Park District. Midway Plaisance Park, http://www.chicagoparkdistrict.com/parks/Midway-Plaisance-Park/ [dostęp 10.02.2016].

23. World's fair, http://en.wikipedia.org/wiki/World's_fair [dostęp 01.03.2016].

24. Sykta I., Wystawy międzynarodowe $i$ ich wptyw na ksztaltowanie krajobrazu miast - próba retrospekcji $i$ wspótczesnej oceny skutków krajobrazowych. The international exhibitions and their impact on the city landscape - an attempt of retrospection and contemporary valorization of their influence on countryside, [w:] Teka Kom. Arch. Urb. Stud. Krajobr. - OL PAN, X/4, Lublin 2014, s. 5-34, http://www.pan-ol.lublin.pl/wydawnictwa/TArch10_4_2014.html

25. Sykta I., Parki Barcelony - od stylu modernisme po wspótczesne krajobrazy tworzone „od-nowa”, [w:] Architektura krajobrazu. Studia i Prezentacje. 1(34) 2012, Uniwersytet Przyrodniczy we Wrocławiu, Wrocław 2012, s. 106-120.

26. Simonis D., Barcelona, National Geographic, G+J RBA, 2008.

27. The end of the century, the beginning of the century. The 1888 Exhibition.; The Era of the 1929 International Exhibition. The first third of the 20th century.

http://www.ben.es/publicacions/Ben_escultures/info/chapter4.html (dostęp 01.06.2016).

28. Jellicoe G. \& S., The Landscape of Man, Thames\&Hudson, Londyn 2006.

29. Modernismo catalán, http://es.wikipedia.org/wiki/Modernismo_catal\%C3\%Aln (dostęp 01.06.2016).

30. 1001 ogrodów, które warto w życiu zobaczyć, Spencer-Jones R. (ed.) / Wojciechowska-Ring D. (red.), Muza S.A., Warszawa 2008.

31. Capó J., Catasús A., Barcelona escultures, Ediciones Polígrafa, Barcelona 2003, s. 38.

32. Poble Espanyol, http://en.wikipedia.org/wiki/Poble_Espanyol (dostęp 01.06.2016).

33. Banham R., Rewolucja $w$ architekturze. Teoria i projektowanie w „pierwszym wieku maszyny”, Wydawnictwa Artystyczne i Filmowe, Warszawa 1979.

34. Blake P., Form Follows Fiasco. Why Modern Architecture Hasn't Worked, Little, Brown\&Company, Boston 1977.

35. Bonta J.P., Anatomia de la interpretación en arquitectura. Resena semiotica de la critica del Pabellón de Barcelona de Mies van der Rohe, G. Gilli, Barcelona 1975.

36. Haduch B., Haduch M., Architectourism. 01. Hiszpania, ZOCO, Kraków 2012.

37. Koolhaas R., Deliryczny Nowy Jork. Retroaktywny manifest dla Manhattanu, Karakter, Kraków 2013.

38. Olszewski A.K., Wystawa nowojorska w 1939 roku. Program i realizacja. [w:] Sosnowska J.M. (red.), Wystawa Nowojorska 1939. Materiały z sesji naukowej Instytutu Sztuki PAN Warszawa, 23-24 listopada 2009 roku, Instytut Sztuki Polskiej Akademii Nauk, Warszawa 2012.

39. Cotter B., Images of America The 1939-1940 New York World's Fair, New_York_1939_booksamplepages_Images of America The 1939-1940 New York World's Fair_Bill Cotter. Pdf (dostęp 12.04.2015).

40. Nowakowska-Sito K., Inżynierowie maszyn i dusz: nowojorska wystawa światowa 1939 roku a modernistyczna utopia lat trzydziestych, [w:] Sosnowska J.M. (red.), Wystawa Nowojorska 1939. Materiały z sesji naukowej Instytutu Sztuki PAN Warszawa, 23-24 listopada 2009 roku, Instytut Sztuki Polskiej Akademii Nauk, Warszawa 2012.

41. Cotter B., Young B., Images of Modern America. The 1964-1965 New York World's Fair, Arcadia Publishing, Charleston, South Karolina, USA 2014.

42. Sykta I., Ewolucja idei postępu i wizji miast przyszłości zapisana w krajobrazach, obiektach i pokazach wystaw światowych - od Brukseli 1958 do Osaki 1970. Evolution of the idea of pro- 
gress and visions of future cities encoded in the landscapes, architectural structures and shows of world exhibitions - from Brussels 1958 to Osaka 1970. [w:] Przestrzeń i Forma'22/2014, s. 103122; http://www.pif.zut.edu.pl/pif22-2.php

43. Lasiewicz-Sych A., Strategia tworzenia miejsc - szkic o architekturze Seattle. Strategy of Pleacemaking - an Essay on Seattle Architecture, [w:] Wspótczesne problemy w architekturze i urbanistyce. Contemporary Problems in Architecture and Urbanism. Tom VII. Volume VII. Czasopismo Techniczne. Architektura. Zeszyt 3-A(3) (112) (2015) 97-125.

44. Cotter B., Images of America. Seattle's 1962 World's Fair, Arcadia Publishing, Charleston, South Karolina, USA 2010.

45. Alaska-Yukon-Pacific Exposition, https://en.wikipedia.org/wiki/Alaska\%E2\%80\%93Yukon\%E2\%80\%93Pacific_Exposition (dostęp: 23.05.2016).

46. Hintzen-Bohlen B., Andaluzja. Sztuka i architektura, Wydawnictwo Olesiejuk, Ożarów Mazowiecki 2008.

47. Villa F., Spacerem po Mediolanie. Największe atrakcje miasta, National Geographic, Warszawa 2015.

48. Parki i ogrody, http://otomediolan.pl/zabytki-i-atrakcje/parki-ogrody (dostęp 01.09.2015).

49. Park Sempione, http://www.mediolan.pl/sport-i-wypoczynek/parki/park-sempione (dostęp 01.09.2015).

50. Ogrody Mediolanu, http://www.lot.com/inspiracje/ogrody-zielonego-mediolanu (dostęp 01.09.2015).

51. Milan World's Fair 2015. Guide to the Expo in and around the City, Rizzoli, New York 2014.

52. CityLife Milano Office Tower, http://www.zaha-hadid.com/architecture/citylife-milano/ (dostęp 01.06.2016).

53. CityLife Milan, http://en.wikipedia.org/wiki/CityLife_(Milan) (dostęp 01.06.2016).

54. Skolimowska A., Expo 2015 - architektura globalnej uczty, Architektura Murator 09/2015.

55. Leonardo Icon. Milano, Italy, http://libeskind.com/work/leonardo-icon/(dostęp 26.05.2016).

56. Expo Milano 2015. Extra Guide. Unique itineraries between site and city, Mondadori Electa S.p.A., 24 Ore Cultura sri, Milan 2015.

57. Massimiliano Fuksas, la Fiera di Milano a Rho, http://dontshootmi.com/massimiliano-fuksasfiera-rho/ (dostęp 27.05.2016).

58. Linden G., Creighton P., The Expo Book. A Guide to the Planning, Organization, Design \& Operation of World Expositions, InPark Magazine (IPM) 2008, http://www.microsofttranslator.com/bv.aspx?ref=SERP\&br=ro\&mkt=plPL\&dl=pl\&lp=EN_PL\&a=http\%3a\%2f\%2ftheexpobook.com\%2f. (dostęp 15.05.2014)

59. Lang Z., Min C., Space Planning of the World Expo Area in Shanghai, [w:] The 47th IFLA World Congress, Harmony and Prosperity - Traditional Inheritance and Sustainable Development, IFLA and CHSLA, Suzhou 2010.

60. Iker G. (ed.), Shanghai Transforming. The changing physical, economic, social and environmental conditions of a global metropolis, Actar, Barcelona 2008.

61. Sykta I., Impact of the Shanghai World Exhibition on the city's development and landscape. Wpływ Wystawy Światowej w Szanghaju na rozwój i krajobraz miasta, [w:] The Landscape and Architecture of Historical and Modern China / Krajobraz i architektura historycznych $i$ wspótczesnych Chin, vol.2, Politechnika Krakowska, Seria Architektura, Monografia 527, Kraków 2016, s. 121-156.

62. Expo 2010 Shanghai China [w:] GA Dokument 112. China Today. A.D.A. Edita, Tokyo.

63. A Preliminary Tour of the Expo Site, http://www.expo2010.cn/expo/expo_english/documents/em/node2524/userobjectlai52529.html (dostęp 14.10.2014).

64. Un Tong L., World Expo 2010 Shanghai China. An Analysis of the possible impacts of World Expo 2010 Shanghai on the tourism development, LAP Lambert Academic Publishing, Saarbrucken Germany 2011.

65. Jun D., Nannan D., Shanshui Concepts in Landscape Planning and Design of the Expo Park in Shanghai, [w:] The 47th IFLA World Congress, Harmony and Prosperity - Traditional Inheritance and Sustainable Development, IFLA and CHSLA, Suzhou 2010. 
66. Jing L., Xiangming Z., From "Green Expo" to "Harmonious City": Sustainable Principles of the Planting Design in the World Expo Park of Shanghai, [w:] The 47th IFLA World Congress, Harmony and Prosperity - Traditional Inheritance and Sustainable Development, IFLA and CHSLA, Suzhou 2010.

67. Shanghai Houtan Park by Turenscape, publ. 2.05.2011, http://www.homedsgn.com/2011/05/02/shanghai-houtanpark-by-turenscape/ (dostęp 10.01.2015).

68. Wang L., Houtan Park, publ. 2.05.2013, http://landscapevoice.com/houtan-park\%e5\%90\%8e\%e6\%bb\%a9\%e5\%85\%ac\%e5\%9b\%ad (dostęp dostęp 10.01.2015).

69. Wang L., Houtan Park Shanghai, publ. 27.05.2013, http://land8.com/profiles/blogs/houtan-parkshanghai-china (dostęp 10.01.2015).

70. Huang Y., Shanghai Expo, Thomson Learning, Singapore 2007.

71. Expo 2010, http://en.wikipedia.org/wiki/Expo_2010 (dostęp 10.01.2015).

72. World Expo Museum, http://www.bie-paris.org/site/en/world-expo-museum (dostęp 12.04.2015).

73. 2010 Shanghai, http://www.bie-paris.org/site/en/expos/past-expos/expo-timeline/2010-shanghai (dostęp 10.01.2015).

74. de Dios Perez J., Shanghai Transforming, [w:] Iker G. (ed.), Shanghai Transforming. The changing physical, economic, social and environmental conditions of a global metropolis, Actar, Barcelona 2008.

75. Lynch K., Obraz miasta, Archivolta, Kraków 2011.

\title{
Synergy of World's Exhibitions areas and spatial structures of host cities
}

\section{Izabela Sykta}

\begin{abstract}
Institute of Landscape Architecture, Faculty of Architecture,
\end{abstract} Cracow University of Technology,e-mail: isykta@pk.edu.pl

\begin{abstract}
The organization of the world's exhibition is for the host city a chance to use this global event to build its image and position in the international arena, its own development by improving the quality of public spaces, cultural facilities, transportation, tourism, etc. Usually extensive, often abandoned, neglected or destroyed by industry areas were used to build Expo sites. In this way they were recovered for the city, contributing to its development. After the exhibition, the city receives areas, equipped with necessary architectural, technical and green infrastructure, and the buildings that continue functioning and longer benefit for the city. A result of this operation is a realization of the assumptions of synergy, as synthesis of energy, expressed by the equation , $2+2=5$ ". Usually, the binders that synergistically bind Expo structures with the city, are uniting them strings or zones of public spaces (e.g. Paris 1889, Barcelona 1929, Seattle 1962), and the inclusion of post-Expo sites into the systems of green areas of the city (e.g. Barcelona 1888, Chicago 1893, 1933, Seville 1929, New York 1939, 1964, Shanghai 2010). But not always effective use of the potential of postExpo areas is a success. Sometimes they have remained isolated islands, which although give an attractive offer of a functional use of space, but through lack of urban synergy with the city, are not able to generate such significant benefits, as in the case of structures synergistically related (np. Seville 1992, Milan 2015). The article shows examples of both, effective and bringing a comprehensive range of benefits for the host city, and also misguided attempts of synergistic relationship between post-Expo areas and spatial structures of cities.
\end{abstract}

Keywords: World's Exhibitions, Expo, urban synergy, synergistic network. 